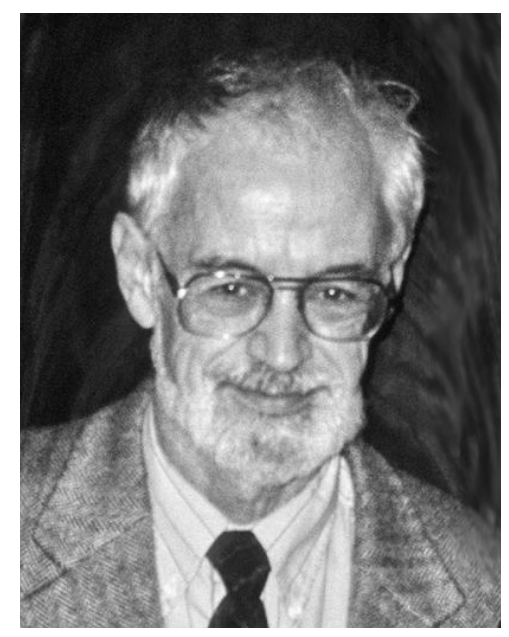

Daniel Waugh. 2003, St. Petersburg, Institute of the Russian Literature (Pushkinsky House)

Даниель Уо. 2003, Санкт Петербург, Институт русской литературы (Пушкинский Дом)

Daniel Waugh. 2013, London, the Royal Geographical Society (foto by Charlotte Green)

Даниель Уо. 2013, Лондон, Королевское географическое общество (фото Шарлотты Грин)

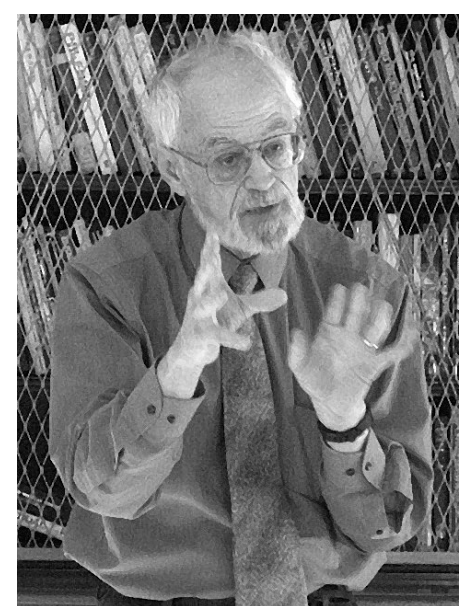

\title{
Scientia
} et vita 


\section{THE ENTHUSIASMS OF YOUTH AND WHERE THEY LED: A MEMOIR ${ }^{1}$}

The article is a continuation of an autobiography written by Daniel Waugh, an eminent American scholar and specialist in Old Russian literature; it gives an original perspective of how a person's life can be combined with professional interest. The events of the author's life are set against a background of Russian studies carried out both in Russia and abroad, as well as historical and cultural discussion. The reader gets acquainted with the Soviet and world humanities thought that intricately combines benevolence and academic objectivity with ideological confrontation and captious objections. The author's perfect understanding of people and their achievements makes the memoirs a source of valuable information on the humanities during the Cold War and postSoviet years. The article demonstrates that respect for hard academic work and mutual respect among scholars is a key to the solution of conflicts and disagreement regardless of their nature. This is the first part of the autobiography, a continuation is to be published in the upcoming issue.

Keywords: Soviet humanities; Pushkin House; Soviet historians; Manuscript Heritage; Old Russian literature.

My interest in manuscripts and codicology perforce led me into filigranology (the study of watermarks), concerning which I had no knowledge prior to arriving in Leningrad in 1968. Of course my initial interest was purely practical, wanting to use paper evidence for dating, but then I at least began to edge into larger concerns about methodology. Not that I ever published much on the subject, beyond a good many reviews and notices on new Russian or Ukrainian publications (most of these for the bulletin of the International Association of Paper Historians). The major exception in substance was long article published in Kritika on my return from my first year in Leningrad. Arguably much more than a review, its fate illustrates how possibly good ideas can vanish almost without a trace if published in an obscure place and with no follow-up.

I would remind readers who know Kritika in its new incarnation as a substantial journal of articles and reviews on Russian history that its ancestor was a review journal, subtitled "A Review of Current Soviet Books on Russian History," printed in a limited run from camera-ready type-

${ }^{1}$ Continuation. For the first part see Quaestio Rossica. 2014. No. 2. 
script. It had been initiated by Richard Pipes, a prominent historian of modern Russia, so that his graduate students at Harvard could gain experience in reviewing and publishing. Indeed, work for Kritika was one of the most valuable parts of my graduate training. We shared drafts of reviews, then met at Pipes' home to critique them before undertaking revisions. He had the final say as to whether a review was publishable; he was unsparing in his demands that we write well. But otherwise the basic editing was in our hands. At the end of the academic year, on at least a couple of occasions, all the participants attended a picnic at his lakeside "dacha" in southern New Hampshire. Some may still have (mine has disappeared) a photo taken of the group in the mid-'60s, whose numbers included a good many who became prominent in Russian and East European history across the U.S. in subsequent years: Robert Williams, Daniel Field, Max Okenfuss, Abbott Gleason, William Rosenberg, John Fine, Peter Kenez, Theodore Taranovski...

We decided to publish a special issue devoted to auxiliary disciplines in 1970, my contribution being a review of Soviet watermark publications [Waugh, 1970]. I was later told that my article had been translated into Russian (probably by E. I. Mamatova) and was circulating in the Lenin Library among the old book specialists. ${ }^{2}$ Subsequently it received the attention of Soviet filigranologists, some of whom applauded and others disagreed with its conclusions at the same time that they tended to ignore one of what I thought were the article's important suggestions. A partial translation of it also appeared in German, under an introduction by the pre-eminent paper historian of the time, Theo Gerardy, indicating how important he felt the piece was. ${ }^{3}$ The thrust of the article was in part criticism of a then very prevalent way of "publishing" watermarks in tabular descriptive form (that is, without depicting each and every one of them), which was advocated

${ }^{2}$ Like Amosov (see above) the watermark specialist in the State Historical Museum in Moscow, T. V. Dianova, took issue with my suggestions regarding the value of precise measurements of watermarks, although she did not fully understand what I had meant. See [Дианова] and my summary in English with a response to her criticism: IPH Information, N. F., 11/3-4 (1977), 116. Apparently not having read my article, Yu. V. Andryushajtite cited my views at least to the extent that they had been explained (and contradicted) by Dianova. See: [Андрюшайтите, 19876], which otherwise is a useful survey of the literature for the indicated period.

${ }^{3}$ IPH Information, N. F., 5/3 (1971), 62-66. Apart from Gerardy, the one person in the West who I know read the article with care was John Simmons of All Souls College, Oxford, the estimable Slavic bibliographer and major contributor to the translation, proper editing and publication of important Russian watermark collections. Simmons wrote me two letters in quick succession with pointed criticisms (and some appreciation) of my piece. I take it as lavish praise from him when he said, "you don't miss much, and you are off the ball only occasionally” (!) (J. S. G. Simmons to Daniel Waugh, 10 July 1970). He was skeptical about the possibilities of computerizing watermark images and felt that the experienced eye of experienced filigranologists really was the best guarantee that papers could be identified. (J. S. G. Simmons to Daniel Waugh, 11 July 1970). Simmons appreciated my comments on the importance of watermark data for codicological study, comments which unfortunately had not been seen (along with related work of others) by Predrag Matejić when he wrote his dissertation a couple of decades later in which he proposed as "new" methodologies some of the same ideas, which he was using in compiling his valuable description of the Hilandar Collection at Ohio State University, a collection for which he has long been the curator. 
by Sokrat Aleksandrovich Klepikov, the "dean" of Soviet filigranology. But I think that alone should not have stirred much interest. I was proposing an alternative, in a sense anticipating the future of filigranology, a future which has yet, more than four decades later, not fully arrived. Following Western scholars, I suggested that proper measurement might enable us to obtain numerical data for comparisons of known with unknown watermarks - that is, perhaps by quantifying the process, we could make it all more precise and at least facilitate indexing an image bank. But that was not all. Having precise images of all watermarks was essential for proper comparison. It occurred to me (probably because I had seen a newspaper article on the subject) that the system of scanning, recording and retrieving fingerprint data in a computer, which the FBI had developed, might be adapted for filigranology, since in both cases one is dealing with images containing some detail which had distinct characteristics. ${ }^{4}$ Of course, as with the computerization of manuscript descriptions, the computerization of watermark data was going to require concerted effort of a kind I had no time to commit and would require substantial financing. Eventually in the Soviet Union some interest developed in what we might call "scientific" processing of watermarks. Kashtanov, among others, explored the possible use of precise measurements, but then emphasized the importance of data other than that concerning paper in codicological studies. ${ }^{5}$ A. P. Bogdanov's book [Богданов] on the basics of filigranology is far more than a textbook for beginners. ${ }^{6}$ Among other things, with passing reference to my article, he undertook serious statistical analysis to show that measurements might be used to distinguish and identify watermarks. Even though he failed to mention my proposals about computerization, he wrote several pages on the desirability of it for future watermark studies. I am not aware that Bogdanov's book has had much of an impact, either for training in the proper analysis of watermarks or in its more forward-looking ideas for the future of filigranology. For the application of watermark evidence in the study of Russian manuscripts, the main practical improvements have been publication of some valuable new albums such as those compiled in GIM by T. V. Dianova and V. M. Zagrebin's compilation in the Publichka

\footnotetext{
${ }^{4}$ A confession here - despite my physics major, I had no real idea of the technical issues involved or the mathematical models demonstrating the possibilities for optical scanning which was a field still in its infancy at the time. What I learned came from reading in a textbook on the subject while standing in the book section of the Harvard bookstore. (Such are the dirty little secrets about "scholarship"!).

${ }^{5} \mathrm{His}$ articles appeared in «Записки Отдела рукописей Государственной библиотеки СССР им. В. И. Ленина» (Iss. 38, 40).

${ }^{6}$ A large section of his book was an illustration of the uses of paper evidence for careful codicological analysis, his example being the official investigation record concerning the death of Tsarevich Dmitry in Uglich in 1591. The document's authenticity has been much disputed; Bogdanov's analysis, which concluded that the manuscript does not reflect the actual results of the investigation (but rather, a politically motivated fabrication) certainly goes farther than previous studies in trying to resolve the dispute. Probably the fact that this extended analysis is buried in an obscure (!) book on watermarks explains why a scholar as thorough as Chester Dunning apparently missed it when working on his big book about the Time of Troubles.
} 
of thematic collections of watermarks by cutting and pasting xeroxes from their scattered depictions in various albums. ${ }^{7}$ His compilations are available only there though for use in the one reading room.

As I have recently learned, Briquet's famous collection is now on line as are watermark databases from several specific collections of manuscripts (not from Russia though). Work has been done toward developing optical recognition methodology for watermarks, but apparently the project has stalled for lack of funding. ${ }^{8}$ It is entirely possible that back in 1970 I was overly optimistic as to how easily the then technology could have been adapted to the task. Yet with the advances in digitization of the intervening decades, one surely can hope that soon it will be possible to achieve what I projected back then (even if that somewhat fanciful vision seems to have had nothing to do with any of the more recent developments).

One of the issues that concerned me in writing that article was the degree to which watermark data might be so loosely interpreted as to invalidate arguments based on it regarding the date of manuscripts. This issue was taken up by A. A. Amosov in a penetrating article published in 1981 in which he discussed the need for much more rigorous use of terminology and for a much more precise methodology in recording and describing watermarks [Амосов]. He cited with approval the "harsh but completely justified criticism" I had written in my 1970 article and as well cited the examples I had used in a later piece to illustrate erroneous claims of those who were trying to undermine Edward Keenan's Kurbskii-Groznyi Apocrypha on the basis of the watermarks in the then known manuscripts [Waugh, 1977].

Here I might digress briefly on that second piece, which was my contribution at the 1974 International Slavists Conference in Banff to a session devoted to Keenan's book. At the time the book had appeared, in one of the first reviews, Serge Zenkovsky dismissed out of hand the possibility that what I had written about the dating of the manuscripts might be accurate. I had laid myself open to this by indicating that, of course, I had come to the task with much less experience than my distinguished Russian predecessors who had worked on the material. In my Banff paper, I provided comparison drawings to reaffirm key datings. Inge Auerbach, who was one of Keenan's persistent critics, also spoke at Banff, and in publishing her paper responded to mine by claiming the indicated watermarks undoubtedly could be from much earlier paper. Her examples though showed how little

${ }^{7}$ Zagrebin, who died tragically just short of age 62 "at the very peak of his creative power and life," headed the Old Russian section of the Publichka's rare book division and had for a number of years, as the successor to his senior colleague N. N. Rozov, been the instructor for a course on Slavic palaeography at St. Petersburg University. He had contributed a good many of the descriptions published in the national catalogue of early Slavic Manuscripts and was deeply involved in the project to describe the Pogodin Collection. His obituary took special note of his work in the compilation of the watermark catalogues. See: [Бобров, Рождественская].

${ }^{8}$ The references and links may be found at: <http://www2.warwick.ac.uk/fac/arts/ren/ projects/ publications/lima/paper/describing/databases/>, accessed 26 June 2012. An e-mail exchange with one of the key participants in this project (who has moved on to a different position) confirms that apparently it has been abandoned. 
she understood of the matter. Amosov's point in supporting me, even if undoubtedly he had other reasons to disagree with Keenan, was that indeed, all too often those citing paper evidence had no clear understanding of what "identity" or "similarity" might or might not mean. And, as a real expert in such matters, unlike Zenkovsky and Auerbach, he clearly knew.

One of the virtues of the new edition of the Kurbskii-Groznyi correspondence by Ia. S. Lur'e and Yu. D. Ry'kov published (at least in part) as a rebuttal to Keenan, was that they did not push the paper evidence farther than it merited. They provided detailed manuscript descriptions, including those for many previously unused manuscripts containing the texts. In those descriptions, they cited my data along with those of others. But none of this was to suggest one should try to re-date the manuscripts back into the $16^{\text {th }}$ century. What did, however, change the picture was a later discovery by B. N. Morozov of a previously unknown manuscript of the first Kurbsky letter in a copy that arguably may be some two decades earlier than any of the others - not going back to the lifetime of the putative correspondents but dating to, perhaps, ca. 1600 [Морозов]. ${ }^{9}$ Keenan was understandably skeptical about this discovery, since old paper can lie around unused and scribal hands often can have a long and deceivingly anachronistic life. My impression of the evidence though supports Morozov's assertions about the early date of the manuscript in question. Of course what this does not do, of itself, is prove Keenan was totally wrong, but rather it throws into question the particular scenario he laid out in the book for the creation of the correspondence. He since has come up with additional explanations which would accomodate the new manuscript evidence but still not undermine his doubts about the "genuineness" of the letters. Unless there are yet more surprises awaiting us in the still poorly described Muscovite manuscripts, I strongly suspect that there never will be filigranological evidence to prove or disprove the authorship of Kurbsky and Ivan. For most of us, filigranology is indeed only an "auxiliary" discipline, albeit I think an underappreciated one.

I might add as a footnote here that I did finally meet Sokrat Aleksandrovich Klepikov (at the time, I think, he was pushing 80 and had few years left) in his apartment in Moscow. He was gracious, not offended in the least by my criticism (which he in any event dismissed). In retrospect, I think I had been too categorical in questioning the value of Klepikov's tabulation approach. Over the years in fact I have had no choice but to use his tables for such common watermarks as "foolscap" and "Arms of Amsterdam," with, however, some cognizance of their limitations for precise dating. When he died, John Simmons inquired whether I might write an obituary for Sokrat Aleksandrovich, but I declined, since I simply did not know enough about

\footnotetext{
${ }^{9}$ Morozov, who acknowledges the assistance of A. A. Amosov in identifying the watermarks, admits that those on the particular leaves with the text of the letter are unclear and that there seems to have been some disturbance in the formation of the quires. However, the surrounding paper and the handwriting argue for a date of the end of the $16^{\text {th }}$ century. Among other material, in discussing the "convoy" of the works accompanying the letter, he cites my book on the apocryphal letters of the sultan.
} 
his career. ${ }^{10}$ One of Klepikov's lasting contributions to filigranology and manuscript studies in Russia was his bequeathing his considerable library of watermark albums and literature published in the West to the manuscript division of the Library of the Academy of Sciences in Leningrad. For Soviet repositories, obtaining such expensive books was nigh impossible, but some of them were essential for a proper reference collection. ${ }^{11}$

The fate of another of my long review articles dating from about the same time as the one on watermarks is somewhat curious. Since I had worked in the manuscripts of the Muscovite kuranty (the translations and summaries of foreign news texts) for my dissertation, naturally I was very interested in the appearance in 1972 of the first volume of what was to be a multi-volume, still ongoing publication of those texts. I had talked with one of the editors about the kuranty and received from her a copy of the book. My review of it for Kritika contained some serious suggestions for improvements that might be made in subsequent volumes - the editors had not always properly ordered the manuscript pages containing the texts; the idea that the texts be arranged chronologically by date of entry was flawed, the scope of what might rightly be included in the publication needed broadening, and ideally any of the western sources which could be located should be published along with the Russian translations [Waugh, 1973]. I sent the review off to Moscow where it was politely acknowledged ${ }^{12}$ and duly cited in a subsequent volume, but the recommendations in it were ignored. The review did, however, come to the attention of Ingrid Maier many years later in Uppsala, when she had started to work on the kuranty texts, and this led to our correspondence and ultimately to collaboration on a (still unfinished) book project for which I went off to Sweden for two pleasurable years immediately following my retirement. ${ }^{13}$

\footnotetext{
${ }^{10}$ Simmons then wrote about Klepikov for both The Book Collector and IPH Information. A long, warm appreciation of him is M. V. Kukushkina [Кукушкина]. The somewhat odd appreciation of Klepikov (focussing mainly on his bibliographic contributions on filigranology and their shortcomings) by I. V. Andryushajtite [Андрюшайтите, 1987a], concluded with a hope that someone would pick up where he left off, but to the best of my knowledge that has not happened.

${ }^{11}$ While this was purely an exchange in return for receiving microfilms I needed of manuscripts, I supplied several of the key watermark albums published by the Paper Publications Society to the the Manuscript Division of GIM in 1969 and Follieri's multi-volume reference work of incipits from Greek manuscripts to the Publichka. Russian scholars who had no such "leverage" were often frustrated in their attempts to obtain any microfilm of manuscripts in GIM, then ruled with an iron hand by the formidable Marfa Viacheslavna Shchepkina. I even witnessed there one of the rare occasions when she smiled, on having just returned from the Bulgarian Embassy where she had been decorated with the Order of SS. Cyril and Methodius for her work on early Slavic manuscripts.

${ }_{12}$ Antonina Ivanovna Sumkina to Daniel Waugh, 12 December 1973. I had sent her a year earlier (before my review) a copy of the section of my dissertation on the kuranty and a reference to the standard published guide to $17^{\text {th }}$-century German newspapers, which was very relevant for for their project (Daniel Waugh to A. I. Sumkina, 10 October 1972).

${ }_{13}$ To date, this project has resulted in two articles jointly authored with Professor Maier: How Well Was Muscovy Connected with the World? [Maier, Waugh, 2009]; 'The Blowing of the Messiah's Trumpet': Reports about Sabbatai Sevi and Jewish Unrest in 1665-1667 [Maier, Waugh, 2010]. In addition, I have published News Sensations from the Front: Reportage in Late Muscovy concerning the Ottoman Wars [Waugh, 2008].
} 
Furthermore, now that the long-time editor of the kuranty series in Moscow has died and Maier is involved in the preparation of the new volumes, some of my recommendations of several decades ago are finally being taken into account. ${ }^{14}$

A great deal of progress has been made in the description of early Slavic manuscripts since Likhachev's somewhat pessimistic assessment at the Tikhomirov Readings in 1972. Yet the results are very uneven. Whereas in the $19^{\text {th }}$ century, many of the descriptions we still most value for their detailed identification of texts were compiled by those who had a very deep knowledge of Orthodox religious literature - some in fact were clerics - it is much harder to find individuals nowadays with such training combined with training in the other necessary disciplines. The problem is especially acute, as Likhachev and others pointed out, when it comes to the cataloguing of manuscript collections in the Russian "provinces" where it might even be difficult to find individuals trained to read Muscovite cursive. ${ }^{15}$ In these circumstances, we have descriptions ranging from the minutely detailed ones for certain of the most interesting miscellanies of the Collection of the Monastery of St. Cyril at Beloozero [Каган, Понырко, Рождественская], to sketchy modern supplements to the classic, detailed catalogue of the Synodal Library Collection compiled by A. V. Gorskij and K. I. Nevostruev in the $19^{\text {th }}$ century [Описание рукописей]. We now have the first parts of the Complete Catalogue of Slavonic-Russian Manuscripts [Сводный каталог, 1984, 2002]. As noted above, Klimentina Ivanova's catalogue of the South Slavic Manuscripts in the Pogodin collection is out, though the description of the rest of the collection is still short of the halfway point. There is much more, but the list of collections as yet undescribed in print is legion. Descriptions of collections outside of Russia are also appearing, but with uneven results and an uncertain future. We have Ralph Cleminson's somewhat flawed catalogue of manuscripts in British collections, a longoverdue contribution. ${ }^{16}$ A current project to describe those in Swedish collections is running out of time and money, leaving one to wonder whether the job can be properly finished. ${ }^{17}$ We still lack a proper description of early Slavica in American libraries.

${ }^{14}$ Vesti-kuranty 1656 g., 1660-1662 gg, 1664-1670 gg., 2 pts. (Moscow, 2008-2009) contains in pt. 2 all the foreign sources which Ingrid Maier was able to locate with considerable difficulty in various collections across Europe. Of course that kind of intensive work could not have been carried out by Soviet scholars in an earlier period, partly for want of the means to visit all the collections, partly for want of the requisite languages. Apart from this feature of the publication, Stepan Shamin, one of the other editor/compilers, went to considerable lengths in the introduction to part 1 to correct some of the codicological and chronological problems that had been created by the long-time editor V. G. Dem'yanov's stubbornness in adhering to the approach established in volume 1 of the series. The next volume, which is being prepared by Shamin and Maier, should avoid these problems entirely.

${ }^{15}$ See, for example: [Амосов, Колесников, особ. с. 165.].

${ }^{16}$ I reviewed it positively: [Waugh, 1990]. For a more careful assessment, see the review by W. R. Veder in The Slavonic and East European Review, 88/3 (1990), 521-523.

${ }^{17} \mathrm{I}$ hope I am not reading too much into a personal communication about this which I received from one of the contributors to the project, Alexander Pereswetoff-Morath, in June 2012. 
Of course the still limited state of our knowledge of Slavic manuscript collections means that discoveries in them, some significant, many arguably trivial, will continue to be made for a long time to come. We are witnessing a flood of good editions of major works which had long been known but never properly published. Furthermore, even in collections well known at least for content description and in the case of texts that have long been in print, re-examination of the manuscripts and a careful consideration of palaeographic and codicological features may open new possibilities. In general I found that other scholars in whose footsteps I was following in my first forays in the manuscripts would be very generous in sharing with me information about texts or copies I had not known; this was often a two-way street. I have been embarrassed by not realizing how potentially interesting a text was until this was pointed out to me, and I have also published as "unpublished" a text that in fact had been edited and appeared a couple of years earlier and about whose publication I had not known. ${ }^{18}$

An example of how further digging in manuscript repositories can substantially update earlier work is the rather large body of texts containing various apocryphal correspondences of the Ottoman Sultan, to which I had devoted a chapter of my dissertation, later expanding it into a monograph. ${ }^{19}$ At the time I did the research, the most important source of information was articles by Marina Davidovna Kagan-Tarkovskaya. I found some additional texts and copies of known ones, with the result that my book at the time it appeared was the most complete survey of this material. In just the last few years though, additional work in the archives of the Muscovite government (RGADA), has turned up new copies, among them the originals of what I had determined on the basis of later manuscripts were trans-

${ }^{18}$ I have in mind in the first instance here my «Неизвестный памятник древнерусской литературы: “Грамота государя царя и великого князя Ивана Васильевича всея Руси к Степану, королю польскому”» [Уо, 1972]. I came across it in 1969, not realizing it was a previously unknown text. Led to it by my cryptic reference in Keenan's book, A. A. Zimin did, informed me of the fact, helped me obtain a full copy of the text (which I had not copied), and then generously left me to publish it at the invitation of S. O. Schmidt. The second example is my Two Unpublished Muscovite Chronicles [Waugh, 1979b]. V. I. Koreczkij had published the second of them two years earlier, something I learned only as my article was making its way through the editorial process. He provides a lot of very valuable historical commentary, though I think there is still some useful information in my article regarding the text and the provenance of its manuscript. His article is: [Корецкий].

19 The book is The Great Turkes Defiance [Waugh, 1978]. An important supplement to it is the article I had published earlier unraveling the textual history of correspondence of the Sultan with the Cossacks which Ilya Repin had immortalized in his late $19^{\text {th }}$-century painting. The reference is On the Origin of the 'Correspondence' between the Sultan and the Cossacks [Waugh, 1971]. My argument was that the letters were part of a European tradition of translated apocrypha and probably had not originated among the Cossacks, even if in their later versions they clearly have become "ukrainianized." Given the obscurity of where the article was published, it has been less widely consulted than the book (which is even available in a number of Russian libraries for those who can read the English). For example, it is missing from another frequently cited article on the Cossack correspondence [Friedman], and seems to have had no influence on the many who still wish to believe the $19^{\text {th }}$-century romanticization of the texts as "original" compositions embodying the cultural ethos of the raucous Cossacks. 
lations made in the Muscovite Privy Chancery. ${ }^{20}$ Moreover, more thorough work than I was able to undertake in Western collections of early books has identified precisely the sources for other Muscovite translations I had discussed, sources which had been unknown to me. ${ }^{21}$ While much of this merely confirms my broader conclusions, some of the discoveries suggest that the origins and transmission of certain texts were substanially more interesting than I had imagined. All this is, of course, the kind of normal development we would expect in scholarship, since few studies so exhaust the subject that they can never be revised and improved.

Often it seems that chance or serendipity, not just persistence and thoroughness, are also responsible for discoveries. A scholar looks for one thing, may or may not find it, and stumbles across something else. Illustrating this is the way I came to study the cultural history of Viatka (Hly'nov) in the late $17^{\text {th }}$ and early $18^{\text {th }}$ centuries, a subject I had never imagined earlier might be one of interest to me. There is, however, an important connection with that earlier work, which explains how I stumbled on the subject and what I then was able to do with it. In my study of the apocryphal letters, I had come across reference to a manuscript containing those texts whose whereabouts after 1918 had been unknown, or at least so it seemed. ${ }^{22}$ The eminent historian K. V. Harlampovich had used the manuscript in Kazan and published texts from it in 1918, but then it vanished. In the mid-1970s, on a komandirovka in Central Asia, A. I. Mazunin had re-discovered it in Tashkent and provided a fairly detailed description, not knowing that it was the same book Harlampovich had used long before. ${ }^{23}$

I had the opportunity to visit Tashkent in 1991, my trip to Central Asia first of all for participation in a mountain climbing expedition and then to represent the University of Washington's History Department on an exchange with its counterpart at Tashkent University, where I offered a minicourse on imperial Russia to an unappreciative audience of two students who had no intention of doing any serious work. I had time on my hands and went off to the National Library to try to locate the manuscript (and some others) which Mazunin had described. There was no expectation here that much would come of the material, which I was examining from the perspective of my dissertation research of two decades earlier, a subject I had not been planning to revisit. Simply locating the book was something of a challenge, since the collection had been re-numbered, and the keeper, helpful as he was, had no idea of where to look. I found it eventually from the old inventory lists, spent some time with the manuscript, copying a few

\footnotetext{
${ }^{20}$ See, for example: [Майер, Шамин; Maier, 2006].

${ }^{21}$ See: [Maier, 2008], which identifies the sources for the Slavic translations of pamphlets published in the 1660s concerning the false Messiah, Shabbetai Zvi. I had been the first to publish the kuranty texts about Shabbetai Zvi [Waugh, 1979a]; they have now been republished along with the original sources in the most recent volumes of Vesti-kuranty.

${ }^{22}$ See my description of the manuscript in [Waugh, 1978, p. 275-276].

${ }^{23}$ I had not known of Mazunin's description, published the year before my book appeared, and might in any event not have connected the Tashkent manuscript with the one that had been in Kazan.
} 
texts and recording enough information to supplement Mazunin's description, and then, once home, throwing all this into a file and almost forgetting about it. Come an invitation to contribute to a Festschrift for Ned Keenan, I needed a subject, and thus began to look at the notes. ${ }^{24}$ What I discovered was not only the evidence of the book's provenance (Hly'nov) but the fact that it contained important information for the history local chronicle writing, remarkable evidence about the degree to which this quintessential "backwater" of Russia (later immortalized as such by Saltykov-Shchedrin) was connected with the wider world, and much more. The one large miscellany was a library in itself, whose owner/compiler, a sacristan Semen Popov, could be identified.

In approaching this material, I began to think more broadly about interpretive strategies than I had in my earlier work. That is, instead of wanting merely to reinforce the traditional historiography that there was a kind of inexorable movement in the direction of the "modern world" starting in the $17^{\text {th }}$ century in Muscovy and then accelerating in the time of Peter the Great, I began to wonder whether we might not need a more nuanced approach. ${ }^{25}$ To a degree then, if anything I was beginning to question the whole interpretive framework in which I had placed such texts as the translated apocryphal letters. Viatka, as I came to argue, was neither more "backward" than, nor as "modern" as, the rest of Russia in the Petrine period. ${ }^{26}$ Of course to what degree an analysis focused in the first instance on a single book might demand reassessment of traditional historiographic conventions was another matter, as one of my reviewers later correctly pointed out [Marker].

While working on the Viatka book, I was able to visit the region for the first time, discovering both the riches of the local library and archival collections, and gaining some sense of local cultural and intellectual traditions. All this, I think, stimulated some re-thinking of what was really significant in Russian culture, whose history too often has been told from the perspective of the center, not from that of the regions. Increasingly now, the perspective from the regions is finally getting its due. One of the challenges confronting Western scholars in Soviet times was access. Kirov

\footnotetext{
${ }^{24}$ My contribution to the Festschrift is 'Anatolii's Miscellany' - Its Origins and Migration [Waugh, 1995].

${ }^{25}$ See my somewhat belabored treatment of this thinking in "We Have Never Been Modern: Approaches to the Study of Russia in the Age of Peter the Great [Waugh, 2001]. Quite a bit more might have been included there on the literature about modernization, some key works not having fallen into my purview, but I would defend the basic conclusions of the article (James Cracraft's objections notwithstanding).

26 The book is "История одной книги: Вятка и "несовременность" в русской культуре Петровского времени» [Уо, 2003], which I drafted in Russian but never could have been published without the substanial editorial ministrations of Mariya Kozhevnikova (then a Ph.D. candidate in economics at the University of Washington) and the further professional editing for Bulanin by Olga Novikova, an accomplished specialist on Muscovite chronicles. The decision to use the term "ne-sovremennost"' as an equivalent for "nonmodernity" (itself a kind of neologism) was criticized by S. M. Kashtanov in his review of the book, although at the time the book was published it was not yet common in Russian simply to transcribe the foreign concept "modern" in its various forms.
} 
(once Hly'nov/Viatka) had been a closed city. My first visit there, in 1996, was to attend a conference which the organizers were happy to label "international" thanks to the presence of some half dozen foreign scholars among the 200 or so who participated. I found the welcome and the atmosphere very stimulating; at least one of my American colleagues, who reported on the proceedings later, seemed to find it, well, "provincial." 27

The Tashkent manuscript included a previously unknown version of the "ur-text" which lies at the core of what had long been regarded as the oldest chronicle of Viatka's history [Уo, 1997a]. ${ }^{28}$ My re-examination of this apparently earliest period of writing Viatka's history then led me to yet another manuscript (in the F. A. Tolstoj collection in St. Petersburg, the manuscript not one which I had previously examined), which contained the "authorial version" of another of the early Viatka chronicles and clearly must have been used by the Viatka sacristan Semen Popov. ${ }^{29}$ Furthermore, I was led to re-examine the history of the famous local icon procession involving an image of St. Nicholas, an event which was at the core of a developing sense of regional identity and whose veneration had figured in those early histories. ${ }^{30}$ The history of the icon procession, which was suppressed in the Soviet period but then revived with the collapse of the Soviet Union, is still in need of further work. My review of the evidence suggested that the veneration of the icon (perhaps its very existence) dated from the $16^{\text {th }}$ century, substantially later than what has been commonly believed. Yet the common belief is an article of popular faith, supported by the ecclesiastical authorities, one unlikely to be overturned by any scholarly argument, especially that by a foreigner. One of the other very interesting aspects of the Viatka material was the questions it raised about the contents of local libraries, where there still is much work to be done to reconstruct the contents of collections that came to be dispersed, especially in the $19^{\text {th }}$ and $20^{\text {th }}$

${ }^{27}$ David Goldfrank, in Newsletter of the Early Slavic Studies Association, 10/1 (May 1997), p. 3, where, not that this is really important, he mis-described the content of my paper. Cf. my substantially more enthusiastic description of the visit: [Waugh, 1997], and a second report on my experiences there a few years later, when I returned to do a "presentation" on my book at the Herzen Regional Library and spent time with a student group in Lal'sk, a small town north of Kirov [Waugh, 2004a]. In a brief paper I wrote for a conference I was then unable to attend about the provinces and Russian culture, I pointedly concluded with the rhetorical question as to whether the United States might not be termed "provincial." See [Yo, 2011]. I am indebted to V. G. Vovina-Lebedeva for her editing of my Russian text and for presenting it at the conference in Tobolsk.

${ }^{28}$ Republished as [Yo, 19976]. Aleksej Musihin is continuing to work on the early Viatka chronicle texts and has re-discovered in the regional archive in Kirov copies that had been used in their publication in the $19^{\text {th }}$ century but then disappeared. Presumably he will produce a new and authoritative edition. However, I have no reason to think that will change my basic conclusions regarding the text I found in Tashkent.

${ }^{29}$ This text, the so-called "Letopisecz stary'h let," is appended to a copy of the "Khronograf of 1617 " in a version with distinct readings which also are found in the works compiled in Hly'nov (the manuscript is RNB F.IV.219 [ex-Tolstoj I.218]). I discuss the text and illustrate its various scribal hands in [ $\mathrm{Y}_{\mathrm{O}}, 2003$, c. 144-159] and provide a critical edition [Ibid, c. 320-331].

${ }^{30}$ See [Waugh, 2004b]; briefly summarized in Russian as [Yo, 2004]. See also the version of some of this material in [ $\left.\mathrm{y}_{\mathrm{o}}, 2006\right]$. 
centuries. To be able to reconstruct the collections of major monastic libraries, as noted above, is one thing, but to deal with the collections of individual churches, lesser monasteries or individuals in the late Muscovite period tends to be more challenging.

My Viatka book would never have been possible without the experience I had gained as a beginner working in Russian manuscripts back in the 1960s and early 1970s. For to a considerable degree, the whole edifice of the book rests on careful codicological analysis of the one manuscript, although contextualized with reference to a great many other historical sources, many of them published by A. S. Vereshchagin, the pioneering founder of the regional historical society at the end of the $19^{\text {th }}$ century. Granted, the work on the Tashkent manuscript is far from perfect, having been done in a library where there were none of the necessary reference works and from which I could not expect to obtain more than a few photographs of individual pages (microfilming the book was impossible). ${ }^{31}$ Having a second opportunity to examine it and flesh out my earlier notes was essential to the ultimate success of the project. This experience, of course, is a good reminder of the challenging conditions scholars working in regional libraries even within Russia may face. For all of the treasures of its collection, the Herzen Regional Library in Kirov lacks most of the important watermark albums; there is apparently a total void of reference works for anyone working on manuscripts owned by the local historical museum. If in Tashkent nowadays probably no one particularly cares about the small collection of Old Slavic books, in Kirov, where there is much more, people do care very much about their collections, but they are handicapped in being able to work with them properly. Even obtaining newer publications of standard scholarship from Moscow and St. Petersburg can be a challenge, since the collapse of the Soviet Union has meant the collapse of the system by which copies of important books were distributed to regional libraries at little or no cost.

I would like to think that my Viatka book is evidence that those early years of apprenticeship in the study of Muscovite manuscripts, inspired and encouraged especially by my Russian colleagues, have really borne fruit in ways that go beyond a somewhat uninspiring focus on solving little problems concerning texts and contexts or paper evidence. With a little luck, there will be yet at least one more book to come out of that early work, a study of the Muscovite acquisition of foreign news, on which I had hoped at one point to write a monograph, abandoned it, but then revived the project in collaboration with Ingrid Maier. That book is likely to look quite different from what it might have been, had it been completed in the 1980s,

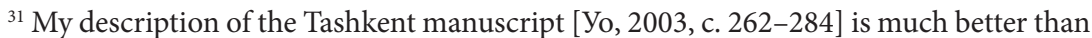
anything I had done for Keenan's book or my own monograph on the sultan's letters. That said, there are still many loose ends - texts needing proper identification, additional work on the watermarks, of which I at least provided some sketchy drawings, analysis and depiction of the various hands. I was able to use one of the other books known to have been in the same personal library of Semen Popov only via a partial xerox obtained from Kazan for me thanks to the efforts of S. M. Kashtanov and E. S. Smirnova. 
since I find myself wanting to ask different questions of the texts and contextualize them in ways I would not have thought of then. The excursion out in to the Russian provinces to Viatka has had a lot to do with re-orienting and, somewhat ironically, broadening my thinking. I had always intended that the book on news place the Muscovite material in a comparative context of news acquisition and dissemination elsewhere in Europe. Now though, I can see how the Muscovite context itself has to be expanded beyond a discussion of the role of the Diplomatic Chancery in Muscovy's "Westernization." For the interest of some of the translated news reports and pamphlets can perhaps better be understood if situated with reference to popular belief in providential interpretations of history and miracle tales and popular religious practice (for example, icon processions and pilgrimage). Informal or "traditional" means of communication (including rumor and gossip), not just the "modern" institutions such as the press and postal system, continued to be extremely important.

So I have moved rather far from wanting to work within the paradigms of Solov'ev and Klyuchevsky and or in emulation of my Russian colleagues' studies of texts, where the focus was often on small problems in part (in Soviet conditions) because many possible larger theoretical and interpretive approaches had to be avoided. It is not as though the value of those scholarly traditions has diminished, for the principles of good scholarship on manuscripts and texts are essential for us to follow today and gradually are filling in the gaps in our knowledge of the sources. There is, however, the danger of remaining too attached late $19^{\text {th }}$-century historical-philological methods in an era when we need to ask new questions and broaden our perspectives if scholarship really is to move forward. Arguably I succeeded beyond any reasonable expectation in shaping my work according to Russian standards, which is why so much of it was readily published there at a time when relatively few foreign scholars were being published in Russia. From the perspective of today, this may all seem unexceptional, when there are collaborative projects, travel to international conferences is common, Western scholars are regularly published in Russian journals (and Russian scholars in Western ones) and their work widely cited (if in Russian translation). Even a short generation has witnessed remarkable change.

There was a downside to my modest success in that earlier era. The kind of work I found myself wanting to do was rather out of step with what was perceived as historical scholarship in American academia. To publish in a language other than English and in journals such as TODRL and $A E$, prestigious as they are in the Russian context, was not necessarily deemed a good credential when being assessed for promotion and tenure. As far as language is concerned, there really was no satisfactory way of reaching both scholarly communities. To publish in English meant that Russian colleagues might never read the work either because they could never get their hands on it or because they could not read the language. It was for that reason that I decided to write the Viatka book in Russian for publication in St. Petersburg, painful as the process was (it might in any event never had 
been accepted by a Western publisher, given its subject matter). Even today, where most Russian scholars can and do interact openly with their Western colleagues, some of those doing the best work have but a limited command of English. Among Russianists outside of Russia, of course there is no language barrier to using Russian publications, though obtaining many of them that appear in small editions and in remote places can still be a challenge. It is imperative in the $21^{\text {st }}$ century that all scholarship become readily available on the Internet.

A real problem in American academia arises when one's scholarship in a foreign language is to be evaluated by colleagues who are not in that field and may not read any language other than English. I had been very fortunate in 1972, the year I finished my dissertation, to obtain one of the two positions then advertised in the U.S. for a historian of pre-modern Russia. ${ }^{32}$ Understandably, few of my colleagues in my home departments could read my work, something which became important at the time promotion was being considered a few years later. Ironically perhaps, my chairman Donald Treadgold, who was a specialist on modern Russia and could read my publications, dismissed them as not being "history." ${ }^{33}$ To write on codicology and watermarks and engage in the analysis and publication of obscure early Russian texts did not fit his concept of what a historian should do. I am not sure the situation would be much different nowadays at other academic institutions in the West, where Russian studies are increasingly seen as irrelevant, and, as my generation retires or dies, the few positions

\footnotetext{
${ }^{32}$ My Harvard adviser, Robert Lee Wolff, whose work was widely known, undoubtedly wrote a strong letter of support for me. Also, it helped that I had participated in a summer Russian language program administered by Herbert Ellison in 1963. He was now a University of Washington historian. At the American Slavic Association convention in Denver in 1971, when the Washington appointment was seen as a possibility, Ellison arranged for me to have breakfast with him and two of my other future colleagues, Donald Treadgold and Peter Sugar. I was not even interviewed for the other position that had been advertised in 1972, at Indiana University, which hired Charles Halperin. The job at the University of Washington, where I would spend my whole career, was initially a one-year appointment to replace Marc Szeftel upon his retirement and thus did not require a full, formal interview process and campus visit (I was still in the USSR when hired). The intent had been to invite a historian of Poland for a year, but when that fell through, the department decided on the one-year appointment as a way of not losing the position entirely. When the decision then was made to continue the early Russia position, the department carried out a proper search in that first year I was on the job. It could well have decided then to hire someone else, as my initial efforts in teaching were not especially impressive.

${ }_{33}$ As history department chair, Treadgold overruled a strong departmental vote that should have promoted me a year ahead of the normal schedule. When my case came up in the following, mandatory review year, I think he was in fact disappointed that I turned down the offer I had received to become head of the Slavic Section of the Harvard University Library, a position I had applied for when uncertain of my tenure prospects. Ned Keenan's strong recommendation that accompanied my application for the Harvard position undoubtedly had a great deal with my receiving the offer there. In retrospect, I think Harvard would have been disappointed, as I would have had far too much to learn to have done the job well. My position at the University of Washington was complicated by my having a joint appointment in History and in International Studies (which meant voting on tenure and promotion was by two different groups of faculty with differing academic priorities). In my final years, I transferred half of my International Studies appointment to the Slavic Department, when I took over the teaching of their course on early Russian Literature and Culture. That is, at the time of my retirement, I was a member of three departments.
} 
devoted to pre-modern Russia are disappearing. We are nearing the day when there will no longer be opportunities in the U.S. for Ph.D. training in pre-modern Russian history, or, for that matter, in many other areas of pre-modern history. ${ }^{34}$

At least in retirement, I no longer worry about obtaining a job or about promotion reviews. I do have to be concerned though that what I write might be worth reading and that there still be audience among the handful of scholars who care as passionately as I do about topics of mutual interest. To the extent that anything valuable has come out of my work, I must acknowledge beyond my graduate mentors the inspiration and support I have received from my Russian colleagues, whose expertise is on a level that I still can but aspire to attain.

УДК $82-94+09+930$

Даниель Уо

\section{УВЛЕЧЕНИЯ ЮНОСТИ И К ЧЕМУ ОНИ ПРИВЕЛИ: АВТОБИОГРАФИЯ}

Статья является продолжением автобиографии видного американского исследователя, специалиста в области древнерусской книжности Даниеля Уо, которая нетривиально показывает сочетание личной судьбы и профессионального интереса. События жизни разворачиваются в контексте отечественной и зарубежной русистики, споров и дискуссий исторического и культурологического характера. Перед читателем открывается панорама советской и мировой гуманитарной науки, где противоречиво соединяются доброжелательность и научная объективность с идеологическим противостоянием и мелочными придирками. Прекрасное понимание людей, оценка их достижений делает воспоминания источником по характеристике состояния гуманитарной науки в напряженные годы «холодной» войны и в постсоветское время.

${ }^{34}$ With my retirement and that of Herbert Ellison, a $20^{\text {th }}$-century specialist, the history department was allowed to fill only one position, and the appointment went to a modernist. The UW Slavic department no longer has a specialist on early Russian literature. During my more than three decades at UW, I supervised only four Ph.D. dissertations in my field (and was an external member of the Ph.D. committee in one other case): Robert Croskey (who wrote on Muscovite diplomatic practice), David Das (on Andrej Ly'zlov's Skifskaya istoriya), Isolde Thyrêt (on women's religious life), Thomas Dykstra (on the Joseph of Volokolamsk Monastery), and Claudia Jensen (at Princeton in music history, writing on Nikolaj Dileczkij). At other universities, recent decades have seen the retirement or death of several prominent American early Russianists, among them Keenan, Robert Crummey, Richard Hellie, and Gustav Alef. In most such cases, they have not been replaced. Several of the best specialists on pre-modern Russia in the next generation teach at institutions where they have no opportunity to train graduate students in the field. News from Western Europe is not any more encouraging for the future of Russian studies, as whole programs are threatened.

* Начало статьи см.: Quaestio Rossica. 2014. № 2.

(C) Уо Д., 2014

Quaestio Rossica · 2014 • №3 
devoted to pre-modern Russia are disappearing. We are nearing the day when there will no longer be opportunities in the U.S. for Ph.D. training in pre-modern Russian history, or, for that matter, in many other areas of pre-modern history. ${ }^{34}$

At least in retirement, I no longer worry about obtaining a job or about promotion reviews. I do have to be concerned though that what I write might be worth reading and that there still be audience among the handful of scholars who care as passionately as I do about topics of mutual interest. To the extent that anything valuable has come out of my work, I must acknowledge beyond my graduate mentors the inspiration and support I have received from my Russian colleagues, whose expertise is on a level that I still can but aspire to attain.

УДК $82-94+09+930$

Даниель Уо

\section{УВЛЕЧЕНИЯ ЮНОСТИ И К ЧЕМУ ОНИ ПРИВЕЛИ: АВТОБИОГРАФИЯ}

Статья является продолжением автобиографии видного американского исследователя, специалиста в области древнерусской книжности Даниеля Уо, которая нетривиально показывает сочетание личной судьбы и профессионального интереса. События жизни разворачиваются в контексте отечественной и зарубежной русистики, споров и дискуссий исторического и культурологического характера. Перед читателем открывается панорама советской и мировой гуманитарной науки, где противоречиво соединяются доброжелательность и научная объективность с идеологическим противостоянием и мелочными придирками. Прекрасное понимание людей, оценка их достижений делает воспоминания источником по характеристике состояния гуманитарной науки в напряженные годы «холодной» войны и в постсоветское время.

${ }^{34}$ With my retirement and that of Herbert Ellison, a $20^{\text {th }}$-century specialist, the history department was allowed to fill only one position, and the appointment went to a modernist. The UW Slavic department no longer has a specialist on early Russian literature. During my more than three decades at UW, I supervised only four Ph.D. dissertations in my field (and was an external member of the Ph.D. committee in one other case): Robert Croskey (who wrote on Muscovite diplomatic practice), David Das (on Andrej Ly'zlov's Skifskaya istoriya), Isolde Thyrêt (on women's religious life), Thomas Dykstra (on the Joseph of Volokolamsk Monastery), and Claudia Jensen (at Princeton in music history, writing on Nikolaj Dileczkij). At other universities, recent decades have seen the retirement or death of several prominent American early Russianists, among them Keenan, Robert Crummey, Richard Hellie, and Gustav Alef. In most such cases, they have not been replaced. Several of the best specialists on pre-modern Russia in the next generation teach at institutions where they have no opportunity to train graduate students in the field. News from Western Europe is not any more encouraging for the future of Russian studies, as whole programs are threatened.

* Начало статьи см.: Quaestio Rossica. 2014. № 2.

(C) Уо Д., 2014

Quaestio Rossica · 2014 • №3 
Замечательно показано, насколько пиетет к кропотливому научному труду и взаимоуважение коллег позволяют преодолеть конфликты и разногласия, какого бы генезиса они ни были.

Ключевы с слов а: советская гуманитарная наука; Пушкинский Дом; советские историки; рукописное наследие; древнерусская литература.

Интерес к рукописям и кодикологии волей-неволей привел меня к филигранологии (изучению водяных знаков), о которой я ничего не знал до приезда в Ленинград в 1968 г. Конечно, изначально моя заинтересованность была чисто практической, связанной с желанием использовать для датировки документальные свидетельства, но постепенно я начал углубляться в ее методологию. У меня не много публикаций по этой теме, если не считать довольно большого количества рецензий и критических отзывов на новые статьи русских и украинских ученых (в основном для периодического издания Международной ассоциации истории бумаги, International Association of Paper Historians). По сути, самое большое исключение - это длинная статья, опубликованная в журнале «Kritika», после того как я вернулся из Ленинграда, проведя там свой первый год. Возможно, судьба этой статьи намного лучше рецензии демонстрирует, как хорошие идеи могут исчезнуть практически без следа, если их опубликовать в малоизвестном издании в недоработанном виде.

Многие читатели знают «Kritika» в новом воплощении как coлидный журнал, печатающий статьи и рецензии по истории России. Я напомню им, что предшественником этого издания был обзорнокритический журнал с подзаголовком «Review of Current Soviet Books on Russian History» («Обзор современных советских книг по истории России»), который печатался небольшим тиражом с оригинал-макета. Этот журнал основал Ричард Пайпс, выдающийся специалист по современной истории России, чтобы его гарвардские аспиранты могли получить опыт рецензирования и издания статей. Несомненно, работа для «Критики» была чрезвычайно важна во время моего обучения в аспирантуре. Мы делились друг с другом набросками рецензий, а затем встречались у Пайпса дома, где обсуждали их, перед тем как вносить исправления. В вопросе о том, будет ли рецензия напечатана, Пайпсу принадлежало последнее слово, и он настойчиво требовал, чтобы мы писали хорошо. Но во всем остальном редактирование было большей частью в наших руках. По крайней мере пару раз в конце учебного года все работавшие над журналом участвовали в пикнике на его «даче», которая располагалась на берегу озера на юге Нью-Хэмпшира. Может быть, у кого-то сохранилась фотография всей компании, сделанная в середине 1960-х гг. (у меня она потерялась). Довольно многие из этих людей впоследствии стали выдающимися специалистами по истории России и Восточной Европы и живут сейчас по всей Америке: это Роберт Уильямс, Даниель Филд, Макс Окенфасс, Эббот Глисон, Уильям Розенберг, Джон Файн, Питер Кенез, Теодор Тарановски... 
В 1970 г. мы решили издать специальный выпуск, посвященный вспомогательным дисциплинам, и я написал для него рецензию на советские работы по водяным знакам [Waugh, 1970]. Позже мне сказали, что моя статья была переведена на русский (возможно, Е. И. Маматовой) и находится в обращении в библиотеке им. Ленина среди старых книг, написанных специалистами в этой области ${ }^{1}$. Впоследствии на мою работу обратили внимание советские филигранологи; одни ей восхищались, другие не соглашались с выводами и при этом, как правило, игнорировали одно из важных, на мой взгляд, предположений статьи. Также появился ее частичный перевод на немецкий; он был издан с введением Тео Джерарди, выдающегося специалиста по истории бумаги того времени, который высказался о значимости работыㄹ. Сутью моей статьи была в том числе критика «издания» водяных знаков в виде таблиц (при котором изображался не каждый водяной знак); этот широко распространенный в то время способ был предложен Сократом Александровичем Клепиковым, «главой» советской филигранологии. Но само по себе это не могло вызвать большого интереса. Я предлагал альтернативу, в определенном смысле предвосхищая будущее филигранологии, которое в полной мере не наступило до сих пор, по прошествии более чем 40 лет. Следуя за западными учеными, я предположил, что правильное измерение позволит получить числовые данные, которые можно будет использовать для сравнения известных водяных знаков с неизвестными. Таким образом, представив процесс в количественной форме, его можно сделать

\footnotetext{
${ }^{1}$ Как и Амосов (см. выше), Т. В. Дианова, специалист по водяным знакам из Государственного исторического музея в Москве, не согласилась с моими предположениями о важности точных измерений водяных знаков, хотя она не вполне поняла, что я имел в виду. См.: [Дианова] и мое резюме на английском, которое я написал в ответ на ее критику (опубл. в: IPH Information. 1977. N. F. Jhrg. 11. Nr. 3-4. S. 116). Ю. В. Андрюшайтите, очевидно не читав моей статьи, сослалась на мои взгляды по крайней мере в тех пределах, в которых их объяснила (и опровергла) Дианова. См.: [Андрюшайтите, 19876]. В других отношениях это полезный обзор литературы по обозначенному периоду.

${ }^{2}$ IPH Information. 1971. N. F. Jhrg. 5. Nr. 3. S. 62-66. Не считая Джерарди, единственный человек на Западе, который внимательно прочел мою статью, - это Джон Симмонс из Колледжа Всех Душ (Оксфорд). Он был уважаемым библиографом-славистом и приложил титанические усилия для перевода, надлежащего редактирования и издания значимых собраний русских водяных знаков. Симмонс написал мне два письма подряд, в которых выразил резкую критику в отношении моей работы (и в то же время высоко оценил ее). Для меня щедрой похвалой являются его слова: «Вы немного упускаете и лишь изредка промахиваетесь» (!) (Дж. С. Г. Симмонс - Даниелю Уо, 10 июля 1970). Он скептически относился к возможностям компьютеризации изображений водяных знаков, считая, что лучшая гарантия идентификации документов - опытный взгляд филигранологов (Дж. С. Г. Симмонс - Даниелю Уо, 11 июля 1970). Симмонс оценил мои замечания о важности филигранологических данных для изучения рукописей. К сожалению, эти замечания (как и работы других людей в данной области) не увидел Предраг Матеич, когда двадцать лет спустя в своей диссертации среди «новых» методологий предложил те же идеи, которые использовал при описании собрания рукописей монастыря Хиландар в Университете штата Огайо. Этим собранием он заведовал в течение долгого времени, и его описание обладает большой ценностью.
} 
более точным и, во всяком случае, использовать для создания указателя изображений в базе данных. Но и это еще не все. Для верного сопоставления было необходимо иметь четкие изображения всех водяных знаков. Мне пришло на ум (возможно, потому, что я видел в газете статью на эту тему), что компьютерную систему сканирования, записи и извлечения данных отпечатков пальцев, разработанную ФБР, можно применить для филигранологии: в обоих случаях мы имеем дело с изображениями, которые содержат детали с индивидуальными характеристиками ${ }^{3}$. Конечно, подобно компьютеризации описаний рукописей, компьютеризация данных водяных знаков требовала таких совместных усилий, на которые у меня не было времени, а также значительного финансирования. Со временем в Советском Союзе мой интерес привел меня к тому, что можно назвать «научной» обработкой водяных знаков. Каштанов наряду с другими изучал, как можно использовать точные измерения, но затем стал подчеркивать важность данных иного рода для исследования бумаги в рамках кодикологии ${ }^{4}$. Книга А. П. Богданова по основам филигранологии [Богданов] - это далеко не просто учебник для начинающих 5 . Помимо всего прочего А. П. Богданов предпринял серьезный статистический анализ, продемонстрировав, что измерения водяных знаков можно использовать для их распознавания и идентификации. В этом анализе он бегло ссылается на мою статью; не упомянув моих предложений по компьютеризации, он, однако, посвятил несколько страниц размышлениям о том, как важен этот процесс для будущих исследований водяных знаков. Насколько я знаю, работа Богданова не внесла значимого вклада в науку в области обучения правильному анализу водяных знаков, как и его новаторские идеи касательно будущего филигранологии. Что касается использования водяных знаков в качестве свидетельств при изучении русских рукописей, большее значение имела публикация ряда новых сборников, в том числе составленных в Государственном историческом музее (ГИМ) Т. М. Диановой и В. М. Загребиным: эти ученые работали в Публичке и создавали

\footnotetext{
${ }^{3}$ Здесь я должен признаться: хотя моим профильным предметом в Йельском университете была физика, на самом деле я ничего не понимал в технических вопросах, связанных с этой темой. Не разбирался я и в математических моделях, демонстрирующих возможности оптического сканирования (в то время эта область еще только зарождалась). То, что я знал, почерпнуто из учебника, который я прочитал, стоя в книжном магазине «Harvard». (Вот такие маленькие грязные тайны скрывает «наука»!)

${ }^{4}$ Его статьи издавались в «Записках Отдела рукописей ГБЛ» (вып. 38, 40).

5 Значительная часть книги является иллюстрацией того, как бумажные свидетельства используются для тщательного кодикологического анализа. В качестве примера приводится запись официального расследования смерти царевича Дмитрия в Угличе в 1591 г. Возникало множество споров насчет подлинности этого документа; Богданов делает вывод о том, что рукопись не отражает настоящих результатов расследования (и, скорее, была подделана по политическим причинам), и в попытке разрешить дискуссию он, несомненно, достигает большего, чем предыдущие исследователи. То, что этот обширный анализ скрыт в туманной (!) книге о водяных знаках, возможно, объясняет, почему Честер Даннинг (ученый, очень тщательно подходящий к работе) пропустил его, трудясь над своей большой книгой о Смутном времени.
} 
тематические сборники водяных знаков, вырезая и вклеивая ксерокопии их разрозненных изображений, находящихся в различных собраниях ${ }^{6}$. Доступ к работам Загребина существует только в этой библиотеке, но зато в том самом читальном зале, где трудился ученый.

Как я недавно узнал, сейчас есть доступ онлайн к знаменитому собранию Брике, как и к базам данных по водяным знакам из нескольких особых собраний рукописей (хотя это рукописи не из России). Проводилась работа по развитию методики оптического распознавания водяных знаков, но, очевидно, этот проект заглох из-за недостаточного финансирования ${ }^{7}$. Вполне возможно, что в далеком 1970 г. я был слишком оптимистичен, полагая, что легко можно приспособить к этой задаче тогдашние технологии. Однако благодаря продвижениям в области оцифровывания, которые произошли за несколько десятилетий, безусловно, можно надеяться, что скоро станет возможным то, что я задумал уже тогда (хотя между моим несколько фантастическим видением и последними разработками нет ничего общего).

Одной из проблем, которая беспокоила меня при написании статьи в 1970 г., было то, что данные водяных знаков могут быть интерпретированы настолько неточно, что лишают состоятельности аргументы, основанные на этих данных и касающиеся даты создания рукописей. Эту же проблему поднял А. А. Амосов: в своей статье 1981 г. он проницательно говорит о том, что необходимо более строго пользоваться терминологией, а также о важности более четкой методологии в области учета и описания водяных знаков [Амосов]. Он с одобрением процитировал «жесткую, но полностью оправданную критику», которую я высказал в своей статье 1970 г. Также он процитировал примеры, которые я привел в более поздней работе: ими я хотел проиллюстрировать, как ошибались те, кто пытался опровергнуть «Апокрифические сочинения Курбского - Грозного» Эдварда Кинана, исходя из водяных знаков, присутствующих в рукописях, известных в то время [Waugh, 1977].

Здесь я позволю себе краткое отступление и расскажу об этой второй статье, которую я написал для международной конференции славистов, проходившей в 1974 г. в Банфе, для заседания, посвященного книге Кинана. Когда эта книга вышла, Сергей Зеньковский в одной из первых рецензий решительно заявил, что мои утверждения

${ }^{6}$ Загребин трагически умер, не дожив до 62 лет, «на самой вершине жизни и творческой энергии». Он возглавлял секцию древнерусской литературы отдела редких книг в Публичке и на протяжении нескольких лет как преемник своего старшего коллеги Н. Н. Розова вел курс по славянской палеографии в Санкт-Петербургском университете. Создал множество описаний, которые вошли в национальный каталог раннеславянских рукописей, и принимал активное участие в проекте по описанию Погодинского собрания. В некрологе Загребина особое внимание обращалось на его работу по составлению каталогов водяных знаков. См.: [Бобров, Рождественская].

${ }^{7}$ Информацию и ссылки можно найти по адресу: http://www2.warwick.ac.uk/fac/arts/ ren/projects/ publications/lima/paper/describing/databases/ (дата обращения 26.06.2012). Обмен электронными письмами с одним из ведущих участников проекта (перешедшим на другую должность) подтвердил, что работа в этом направлении прекратилась. 
о датировке рукописей неверны. Я навлек на себя подобное обвинение, признав, что, несомненно, у меня намного меньше опыта, чем у моих выдающихся русских предшественников, которые работали с этим материалом. В статье 1974 г. я сопоставил изображения водяных знаков, чтобы подтвердить важнейшие датировки. Инге Ауэрбах, одна из тех, кто упорно критиковал Кинана, также выступала на конференции в Банфе. В своей статье она ответила на мою, заявив, что указанные водяные знаки вполне могут относиться к намного более раннему документу. Однако из ее примеров было ясно, что она плохо разбирается в данном вопросе. Амосов поддержал меня, хотя, бесспорно, у него были другие причины спорить с Кинаном; он согласился, что зачастую, приводя документальные свидетельства, ученые плохо представляют, что значит «подлинность» и «сходство». А он определенно это понимал, будучи настоящим специалистом в этих вопросах, в отличие от Зеньковского и Ауэрбах.

Я. С. Лурье и Ю. Д. Рыков выпустили новое издание переписки Курбского и Грозного, чтобы опровергнуть доводы Кинана (по крайней мере отчасти такова была их цель). Одно из достоинств этого издания состоит в том, что авторы не придают документальным свидетельствам большего значения, чем те заслуживают. Лурье и Рыков подробно описывают рукописи, среди которых есть много ранее не описанных. Авторы ссылаются на мои данные наряду с данными других исследователей. Но при этом не говорится, что необходимо изменить датировку рукописей и отнести их к XVI в. Картину изменило открытие, которое позже сделал Б. Н. Морозов: он обнаружил ранее неизвестный список первого письма Курбского, который, возможно, был создан примерно на двадцать лет раньше, чем все другие рукописи, и относится не ко времени жизни предполагаемых корреспондентов, а примерно к 1600 г. [Морозов] ${ }^{8}$. Кинан отнесся к этому открытию скептически, что понятно: старая бумага может лежать без дела, а почерки переписчиков зачастую долго не меняются и вводят в заблуждение своей мнимой архаичностью. Я, напротив, поддерживаю утверждение Морозова о раннем создании данной рукописи. Конечно же, само по себе открытие Морозова не доказывает, что Кинан был совершенно не прав; скорее ставится под вопрос конкретный сценарий создания переписки, изложенный им в книге. Впоследствии Кинан привел дополнительные объяснения, которые вписывают новые рукописные свидетельства в общую картину, но и не подрывают его сомнения в «подлинности» писем. Рукописи периода Московского государства, которые до сих пор плохо описаны, преподнесут еще много неожиданностей, но мне кажется, что филигранологические

\footnotetext{
${ }^{8}$ Морозов, признавая, что А. А. Амосов помогал ему идентифицировать водяные знаки, замечает, что на некоторых листах с текстом письма знаки неясны и что, должно быть, листы были соединены беспорядочно. Однако бумага и почерк позволяют отнести рукопись к концу XVI в. Говоря о «свите» работ, окружающих это письмо, Морозов наряду с другим материалом ссылается на мою книгу об апокрифических письмах султана.
} 
свидетельства, которые позволят доказать или опровергнуть авторство Курбского и Ивана Грозного, никогда не появятся. Для большинства из нас филигранология, несомненно, является лишь «вспомогательной» дисциплиной, хотя, как мне кажется, ее недооценивают.

Здесь я мог бы добавить сноску и написать, что я все-таки встретился с Сократом Александровичем Клепиковым в его московской квартире (по-моему, тогда ему было под восемьдесят, и жить ему оставалось недолго). Он был очень любезен и совершенно не обижался на мою критику (которую он в любом случае не принимал). Оглядываясь назад, я думаю, что был слишком категоричен, ставя под сомнение ценность табличного метода Клепикова. В сущности, годами уменя не было иного выбора, кроме как использовать его таблицы для описания часто встречающихся водяных знаков (например, «шутовского колпака» и «герба Амстердама»). Но я осознавал, что возможности точной датировки при этом методе ограничены. Когда Сократ Александрович умер, Джон Симмонс спросил, не мог бы я написать некролог, но я отказался, потому что просто-напросто недостаточно знал о его карьере 9 . Один из долговечных вкладов Клепикова в российскую филигранологию и изучение рукописей состоял в том, что он завещал свою большую библиотеку альбомов с водяными знаками и западной литературы по ним Отделу рукописей Ленинградской библиотеки РАН. Для советских хранилищ было почти невозможным получить такие дорогие книги, но некоторые из них были необходимы для надлежащего собрания справочных материалов ${ }^{10}$.

Любопытна судьба еще одной моей большой рецензии, примерно того же времени, что и статья о водяных знаках. Во время работы над диссертацией я изучал рукописи московской газеты «Куранты» (в которой издавались переводы и краткие изложения иностранных новостных текстов), поэтому меня очень заинтересовало появление в 1972 г. первого тома, в котором были опубликованы эти тексты (проект вылился в многотомный труд, и тексты издаются до сих пор). Я поговорил с одним из редакторов о «Курантах», и она подарила мне экземпляр книги. Я написал на нее рецензию для журнала «Kritika», где предло-

9 Тогда Симмонс написал о Клепикове в два издания: «The Book Collector» и «IPH Information». Большую и теплую статью о нем написала М. В. Кукушкина [Кукушкина]. В статье Ю. В. Андрюшайтите заслуги Клепикова оцениваются несколько странно: автор сосредотачивает внимание главным образом на его вкладе в библиографию филигранологии и недостатках его подходов [Андрюшайтите, 1987a]. В завершение статьи Ю. В. Андрюшайтите выражает надежду, что кто-нибудь продолжит дело Клепикова, но, насколько я знаю, этого не произошло.

${ }^{10}$ В 1969 г. я передал Отделу рукописей ГИМ несколько важнейших альбомов водяных знаков, изданных обществом «Paper Publications Society», а Публичке - многотомный справочник инципитов из греческих рукописей, написанный Фоллиери. Но в обмен я смог получить необходимые мне микрофильмы рукописей. Русским ученым, не имевшим подобного «рычага», часто были недоступны микрофильмы рукописей в ГИМ, которым в то время управляла железной рукой грозная Марфа Вячеславовна Щепкина. Я даже наблюдал один из редких случаев, когда она улыбалась: она только что вернулась из посольства Болгарии, где ее наградили орденом «Святые Кирилл и Мефодий» за работу над раннеславянскими рукописями. 
жил несколько серьезных улучшений, которые можно было учесть в последующих томах. Редакторы не всегда располагали страницы рукописей в правильном порядке; неверным был замысел помещать тексты хронологически, по дате издания; необходимо было расширить границы материала, который можно было по праву включить в издание; и в идеале вместе с русскими переводами следовало печатать все западные источники, которые можно найти [Waugh, 1973]. Я отослал рецензию в Москву, где ее вежливо приняли ${ }^{11}$ и должным образом опубликовали в последующем номере, но рекомендации были проигнорированы. Однако много лет спустя в Упсале мою рецензию заметила Ингрид Майер, начавшая исследовать тексты «Курантов»; в результате между нами завязалась переписка, и в конце концов мы стали вместе работать над проектом книги (который еще не завершен). Для этой работы сразу же после выхода в отставку я уехал в Швецию, где провел два приятных года ${ }^{12}$. Более того, теперь, после смерти человека, который долгое время был редактором московской серии «Курантов», Майер участвует в подготовке новых томов, и, наконец, принимаются во внимание некоторые предложения, которые я сделал несколько десятилетий назад ${ }^{13}$.

Многое было сделано в описании раннеславянских рукописей с 1972 г., когда на Тихомировских чтениях Лихачев заявил, что эта область развивается медленно. К тому же результаты очень неравномерны. В XIX в. многие описания, которые до сих пор высоко ценятся за подробную идентификацию текстов, составили люди, обладавшие глубочайшими знаниями православной религиозной литературы (некоторые из них были служителями церкви). Сейчас намного сложнее найти специалистов, хорошо подготовленных как в этой, так и в других необходимых областях. Как указывали Лихачев

${ }^{11}$ Антонина Ивановна Сумкина - Даниелю Уо, 12 декабря 1973 г. Годом ранее (до рецензии) я прислал ей экземпляр раздела моей диссертации, посвященного «Курантам», и сослался на классический справочник по немецким газетам XVII в., что было очень важно для этого проекта. (Даниель Уо - А. И. Сумкиной, 10 октября 1972 г.).

${ }^{12}$ На сегодняшний день работа над этим проектом привела к публикации двух статей совместно с профессором Майер: «How Well Was Muscovy Connected with the World?» («Насколько сильна была связь Московского государства с миром?»), см.: [Maier, Waugh, 2009]; “"The Blowing of the Messiah's Trumpet”: Reports about Sabbatai Sevi and Jewish Unrest in 1665-1667» («"Трубный глас Мессии”: Сообщения о Шабтае Цви и еврейских волнениях 1665-1667 гг.»), см.: [Maier, Waugh, 2010]. Более того, я опубликовал статью «News Sensations from the Front: Reportage in Late Muscovy concerning the Ottoman Wars» («Сенсации с фронта: репортажи об Османских войнах в позднем Московском государстве», см.: [Waugh, 2008].

${ }_{13}$ «Вести-Куранты 1656 г., 1660-1662 гг., 1664-1670 гг.» (в 2 ч. М., 2008-2009); во второй части содержатся все иностранные источники, которые Ингрид Майер с большим трудом удалось найти в различных европейских собраниях. Конечно же, раньше советские ученые не смогли бы провести настолько тщательную работу отчасти из-за отсутствия средств, чтобы посетить места хранения всех собраний, отчасти из-за незнания необходимых языков. Помимо этой особенности издания Степан Шамин, еще один редактор-составитель, написал объемное введение к первой части, в котором исправил некоторые кодикологические и хронологические недочеты; они были допущены из-за того, что В. Г. Демьянов, долгое время работавший в качестве редактора, упрямо придерживался подхода, который был установлен в первом томе серии. В следующем томе, который готовят Шамин и Майер, этих недочетов не должно быть совсем. 
и другие, эта проблема особенно обостряется, когда дело касается каталогизирования рукописных собраний в российской провинции: там бывает трудно даже просто найти тех, кто умеет читать московскую скоропись ${ }^{14}$. В таких обстоятельствах появляются совершенно разные описания: от скрупулезных работ по некоторым из интереснейших сборников из собрания Кирилло-Белозерского монастыря [Каган, Понырко, Рождественская] до поверхностных дополнений к классическому подробному каталогу собрания Синодальной библиотеки, который был составлен в XIX в. А. В. Горским и К. И. Невоструевым [Описание рукописей]. Сейчас есть первые части «Сводного каталога славяно-русских рукописных книг» [Сводный каталог, 1984, 2002]. Как я уже писал, вышел каталог по южнославянским рукописям из Погодинского собрания, составленный Климентиной Ивановой, но остальная часть собрания не описана еще и наполовину. Есть еще много работ, но количество не описанных в печати собраний огромно. Появляются также описания собраний, хранящихся не в России, но результаты этой работы неупорядочены, а будущее неопределенно. У нас есть каталог рукописей из британских собраний, который следовало издать уже давно; он составлен Ральфом Клеминсоном, и в нем довольно много неточностей ${ }^{15}$. Существует также проект по описанию рукописей из шведских собраний, но у его создателей не хватает ни времени, ни денег, и неясно, будет ли эта работа завершена надлежащим образом ${ }^{16}$. Все еще нет должного описания ранней литературы о славянах, содержащейся в американских библиотеках.

Несомненно, из-за того, что наши знания о славянских рукописных собраниях ограничены, в этой области еще долго будут совершаться открытия как значительные, так и довольно банальные. Мы наблюдаем поток хороших изданий важнейших работ, давно известных, но не опубликованных надлежащим образом. Более того, даже в случае с собраниями, которые хорошо известны хотя бы описанием своего содержания, и с текстами, изданными давно, могут открыться новые возможности благодаря переоценке рукописей и тщательному анализу их палеографических и кодикологических особенностей. В целом я убедился, что ученые, по чьим стопам я шел, делая первые попытки в изучении рукописей, щедро делились со мной информацией о неизвестных мне текстах и списках; в этот период я часто совершал противоположные ошибки. В одном случае мне было неудобно, что я не понимал, какой потенциальный интерес представляет текст, пока мне на это не указали; в другом я издал как «неопубликованный»

\footnotetext{
${ }^{14}$ См., например: [Амосов, Колесников, особ. с. 165].

15 Я положительно отозвался об этой работе в рецензии [Waugh, 1990]. Более подробную оценку см. в рецензии У. Р. Ведера (W. R. Veder) в журнале «The Slavonic and East European Review» (1990, vol. 88, no. 3, p. 521-523).

${ }^{16}$ Надеюсь, я не слишком вольно интерпретирую личное письмо на эту тему, полученное мной в июне 2012 г. от Александра Пересветова-Мурата, одного из участников проекта.
} 
текст, который на самом деле уже был отредактирован и вышел двумя годами ранее, о чем я не знал ${ }^{17}$.

Если продолжить копаться в хранилищах рукописей, можно существенно улучшить ранее написанную работу; пример этого - довольно большой массив текстов, содержащих апокрифическую переписку османского султана (ей посвящена глава моей диссертации, которая затем расширилась до монографии $)^{18}$. Когда я проводил это исследование, важнейшим источником информации для меня были статьи Марины Давидовны Каган-Тарковской. Я нашел дополнительные тексты и списки уже известных, и в результате, когда моя книга появилась, она была самым полным обзором данного материала. Лишь в последние несколько лет дальнейшая работа в архивах правительства Московского государства (РГАДА) позволила обнаружить новые списки, и среди них - оригиналы переводов, сделанных в Приказе тайных дел (ранее я установил, что представляют собой эти тексты, на основе более поздних рукописей $)^{19}$. К тому же благодаря исследованию западных собраний древних книг (на такую тщательную работу я не был способен) были точно установлены неизвестные мне источники других переводов периода Московского государства, которые я рассматривал ${ }^{20}$. Многие из этих открытий лишь подтверждают сделан-

${ }^{17}$ В первом случае я имею в виду мою статью [Уо, 1972]. Я столкнулся с этим текстом в 1969 г., не понимая, что ранее он был неизвестен. А. А. Зимин, которого привела к нему сделанная мной в книге Кинана неявная ссылка и который знал, что ранее этот текст не издавался, сообщил мне об этом, помог достать полный его экземпляр (который я не скопировал) и великодушно предоставил мне его опубликовать по предложению С. О. Шмидта. Второй пример - это статья «Two Unpublished Muscovite Chronicles» («Две неизданные летописи периода Московского государства») [Waugh, 1979b]. Двумя годами ранее В. И. Корецкий опубликовал вторую из них, но я узнал об этом, только когда моя статья уже редактировалась. В его работе много ценнейших исторических комментариев, но, мне кажется, в моей статье все же есть полезные сведения о тексте и о происхождении рукописи. Статья В. И. Корецкого называется «Безднинский летописец конца XVI в. из собрания С. О. Долгова» [Корецкий].

18 Это книга «Вызов Великого турка» [Waugh, 1978]. Важное дополнение к ней статья, которую я опубликовал ранее; в ней раскрывается текстуальная история переписки султана с казаками, которую в конце XIX в. увековечил в своей картине Илья Репин. Статья называется "On the Origin of the "Correspondence" between the Sultan and the Cossacks» («О происхождении “переписки” между султаном и казаками» [Waugh, 1971]. Я утверждал, что эти письма входят в европейскую традицию переводных апокрифов и, возможно, возникли не среди казаков, хотя в более поздних вариантах они, безусловно, «украинизировались». Учитывая то, что эта статья была напечатана в малоизвестном издании, к ней обращаются реже, чем к книге (которая есть даже в некоторых российских библиотеках и доступна тем, кто может читать поанглийски). Например, первая не упоминается в другой часто цитируемой статье, посвященной переписке казаков: [Friedman]. Похоже, моя статья прошла мимо многих, кто все еще хочет верить, что романтизированные тексты XIX в. - это «подлинные» произведения, в которых воплощается дух бунтарей-казаков.

${ }^{19}$ См., например: [Майер, Шамин; Maier, 2006].

${ }^{20}$ См.: [Maier, 2008]. Здесь устанавливаются источники переводов на славянские языки памфлетов о лжемессии Шабтае Цви, изданных в 1660-е гг. Я первым опубликовал тексты «Курантов» о Шабтае Цви в статье «News of the False Messiah: Reports on Shabbetai Zevi in Ukraine and Muscovy» («Новости о лжемессии: сообщения о Шабтае Цви в Украине и Москве» [Waugh, 1979a]. Сейчас эти тексты переизданы вместе с первоисточниками в новых томах «Вестей-курантов». 
ные мной более общие выводы, но некоторые предполагают, что оригиналы и переводы определенных текстов представляют значительно больший интерес, чем я думал ранее. Несомненно, все это обычное развитие науки: немногие исследования являются настолько исчерпывающими, что их невозможно пересмотреть и усовершенствовать.

Часто кажется, что открытия совершаются не только благодаря упорству и скрупулезности: роль могут сыграть также случайность и интуиция. Ученый ищет одно, находит это или нет и натыкается на что-то другое. Примерно так я и начал изучать культурную историю Вятки (Хлынова) конца XVII - начала XVIII в.: я и не предполагал, что эта тема может меня заинтересовать. Но история Вятки тесно связана с моим предыдущим исследованием; это объясняет, как я наткнулся на эту тему и каким образом смог над ней работать. Изучая апокрифические письма, я увидел ссылку на рукопись, в которой они содержатся; ее местонахождение было неизвестно с 1918 г. (по крайней мере так казалось) ${ }^{21}$. Выдающийся ученый К. В. Харлампович использовал эту рукопись в Казани и в 1918 г. опубликовал тексты из нее; но затем она исчезла. В середине 1970-х находившийся в командировке в Центральной Азии А. И. Мазунин вновь обнаружил рукопись в Ташкенте. Он довольно подробно ее описал, не зная, что это та же книга, которой когда-то пользовался Харлампович ${ }^{22}$.

В 1991 г. мне удалось побывать в Ташкенте; я поехал в Центральную Азию, во-первых, чтобы принять участие в экспедиции по альпинизму, а во-вторых - чтобы представить исторический факультет Вашингтонского университета в ходе обмена с историческим факультетом Ташкентского университета. Я прочитал мини-курс по царской России неблагодарной аудитории из двух студентов, которые не собирались серьезно работать. У меня было время, и я пошел в Национальную библиотеку, чтобы попытаться найти эту и некоторые другие рукописи, описанные Мазуниным. Я не ожидал, что что-то выйдет из материала, который я рассматривал с точки зрения диссертации, написанной мной двадцать лет назад (и я не планировал возвращаться к этой теме). Найти книгу оказалось сложной задачей, потому что собрание было заново пронумеровано, и библиотекарь, несмотря на готовность мне помочь, совершенно не знал, где искать. В конце концов я нашел ее в старой инвентарной описи, провел некоторое время за изучением рукописи, скопировал несколько текстов и записал информацию, которой должно было хватить, чтобы дополнить описание Мазунина. Вернувшись домой, я засунул все это в папку и почти забыл о рукописи. Когда мне предложили написать статью для юбилейного сборника в честь Неда Кинана, я принялся читать

${ }^{21}$ См. мое описание данной рукописи в «Вызове Великого турка» [Waugh, 1978, p. 275-276].

${ }^{22}$ Я не знал об описании Мазунина, которое вышло за год до появления моей книги, и в любом случае не мог связать Ташкентскую рукопись с той, что была в Казани. 
свои записи в поисках темы ${ }^{23}$. Я обнаружил не только свидетельства происхождения книги (Хлынов), но и то, что она содержит важные сведения об истории местного летописания. Я узнал, в какой степени это типичное русское «болото» (позднее подобным словом город увековечил Салтыков-Щедрин) было связано с остальным миром, и многое другое. Один большой сборник сам по себе являлся библиотекой, и можно было установить его владельца-составителя: им был ризничий Семен Попов.

Начиная исследовать этот материал, я стал шире смотреть на приемы интерпретации, которые использовал в прошлых работах. Я хотел не просто поддержать взгляды традиционной историографии на то, что неуклонное движение Московского государства к «современному миру» началось с XVII в. и ускорилось во времена Петра I, я начал задумываться, не нуждаемся ли мы в более детальном подходе $^{24}$. Тогда я в какой-то степени начинал сомневаться и во всей системе

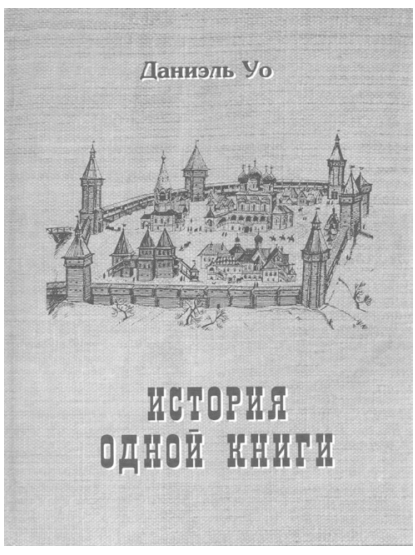
интерпретации, в рамки которой я поместил такие тексты, как переводные апокрифические письма. Я стал утверждать, что Вятка была не бо́льшим «болотом», чем остальная часть России в Петровскую эпоху; но в то же время она не могла сравниться с остальной частью страны по «современности» ${ }^{25}$. Несомненно, это был уже другой вопрос: насколько анализ, основанный преимущественно на одной книге, может потребовать пересмотра традиционных правил историографии; впоследствии один из моих рецензентов верно на это указал [Marker].

${ }^{23}$ Моя статья для этого сборника называется «"Anatolii’s Miscellany” - Its Origins and Migration» (“Анатольевский сборник” - его происхождение и его странствия» [Waugh, 1995].

${ }^{24} \mathrm{CM.} \mathrm{мое} \mathrm{изложение} \mathrm{этого} \mathrm{взгляда} \mathrm{(слегка} \mathrm{перегруженное} \mathrm{подробностями)} \mathrm{«We}$ Have Never Been Modern: Approaches to the Study of Russia in the Age of Peter the Great» («Мы никогда не были современными: Подходы к изучению России эпохи Петра Великого») [Waugh, 2001]. В эту статью можно было бы включить намного больше литературы по модернизации - некоторые ключевые работы не вошли в область моего рассмотрения. Но я всегда отстаивал основные выводы статьи (несмотря на возражения Джеймса Кракрафта).

${ }^{25}$ Моя работа называется «История одной книги: Вятка и “не-современность” в русской культуре Петровского времени» [Уо, 2003]. Я написал ее черновик по-русски, но она бы никогда не вышла, если бы не существенная помощь в редактировании, оказанная Марией Кожевниковой (которая в то время была кандидатом экономических наук в Вашингтонском университете), и профессиональное редактирование для издательства, которым затем занималась Ольга Новикова, опытный специалист по московским летописям. С. М. Каштанов в рецензии на книгу критически отозвался об использовании термина «не-современность» как эквивалента слова «non-modernity» (которое само по себе является неологизмом). Однако в то время, когда издавалась книга, для русского языка еще не было характерно просто транскрибировать иностранный термин «modern» в различных формах. 
Работая над книгой из Вятки, я смог впервые посетить это место открыть богатства вятской библиотеки и архивных собраний и получить представление о местных культурных и интеллектуальных традициях. Думаю, благодаря всему этому я переосмыслил вопрос о том, что действительно важно в русской культуре: слишком часто ее история рассказывается с точки зрения центра, а не регионов. Сейчас наконец все больше ученых отдают должное регионам. Одним из испытаний, с которыми сталкивались западные ученые в советское время, было получение доступа. Киров (некогда Хлынов/Вятка) был закрытым городом. Я приехал туда в первый раз в 1996 г. на конференцию, которая именовалась международной благодаря тому, что среди 200 участников было около полудюжины иностранных ученых. Прием и атмосфера показались мне очень вдохновляющими; по крайней мере один из моих американских коллег, который впоследствии сообщал о ходе конференции, нашел ее, мягко говоря, «провинциальной» ${ }^{26}$.

Ташкентская рукопись содержала до этого неизвестный вариант «пратекста», лежащего в основе летописи, которая долгое время считалась древнейшей в истории Вятки $\left[У_{о}, 1997 \mathrm{a}\right]^{27}$. То, что я пересмотрел этот, очевидно, наиболее ранний период написания истории города, затем привело меня еще к одной рукописи, входящей в собрание Ф. А. Толстого в Санкт-Петербурге, которую я ранее не изучал. Эта рукопись содержит «авторскую версию» другой ранней вятской летописи и, несомненно, использовалась вятским ризничим Семеном Поповым ${ }^{28}$. Более того, это исследование привело меня к пересмотру истории знаменитого местного крестного хода, в котором использовалось изображение св. Николая. Это событие лежало в основе растущего чувства территориальной идентично-

26 Дэвид Голдфранк написал об этом в статье для журнала «Newsletter of the Early Slavic Studies Association» (1997, vol. 10, no. 1, p. 3) (там же он неверно изложил содержание моего доклада, хоть это и не очень важно). Ср. мое намного более воодушевленное описание поездки: [Waugh, 1997]. Несколько лет спустя я опубликовал еще одно сообщение о своих впечатлениях в этом же издании - я вернулся в Киров, чтобы сделать «презентацию» моей книги в Областной библиотеке им. Герцена, и провел некоторое время с группой студентов в Лальске, городке к северу от Кирова [Waugh, 2004a]. Краткий доклад, написанный для конференции, я завершил многозначительным риторическим вопросом: нельзя ли назвать «провинциальными» США? См. мою статью: [Уо, 2011]. Я в долгу у В. Г. Вовиной-Лебедевой за то, что она отредактировала мой русский текст и представила его на конференции в Тобольске.

${ }_{27}$ Статья была переиздана как: [Уо, 1997б]. Алексей Мусихин продолжает исследовать ранние вятские летописные тексты и, работая в Кировском областном архиве, заново обнаружил списки, которые использовались для публикации этих текстов в XIX в., но затем исчезли. Вероятно, Мусихин сделает новое авторитетное издание. Однако у меня нет причин полагать, что это изменит мои основные выводы касательно текста, найденного мной в Ташкенте.

28 Этот текст, так называемый «Летописец старых лет», приложен к списку «Хронографа 1617 года»; в этом варианте текста отчетливо проявляются особенности, присутствующие и в работах, составленных в Хлынове (шифр рукописи: РНБ Ф.IV.219 [ранее в собрании Толстого - И. 218]). Я рассматриваю данный текст и иллюстрирую разные почерки, которые в нем встречаются, в: [Уо, 2003, с. 144-159], а также привожу критическое издание: [Там же, с. 320-331]. 
сти, и о его почитании говорится в тех ранних летописях ${ }^{29}$. История крестного хода, который был запрещен в советское время, но с распадом Советского Союза возродился, до сих пор нуждается в дальнейшем исследовании. В обзоре свидетельств я предполагаю, что почитание иконы (а возможно, и само ее существование) началось в XVI в. - значительно позже, чем обычно считалось. Но это общепринятое мнение связано с народной верой, которая поддерживается церковью и которую едва ли могут ниспровергнуть научные доводы, особенно выдвигаемые иностранцем. Еще одна интересная особенность вятского материала - это поднимаемые им вопросы о содержимом местных библиотек: еще предстоит провести большую работу, чтобы восстановить содержание собраний, которые оказались разбросаны по всему миру, особенно в XIX и XX вв. Как я уже говорил, одно дело - восстанавливать собрания главных монастырских библиотек, но намного более сложная задача - изучать те, которые принадлежат отдельным церквям, небольшим монастырям и частным лицам.

Я бы никогда не написал книгу о Вятке, если бы не опыт, который я получил, еще только начиная работать над русскими рукописями в 1960-х - начале 1970-х гг. В значительной мере вся книга строится на тщательном кодикологическом анализе единственной рукописи, хотя она помещается в контекст множества других исторических источников; многие из них были изданы А. С. Верещагиным, в конце XIX в. основавшим областное историческое общество. Честно говоря, моя работа по ташкентской рукописи далека от совершенства: в библиотеке, где я ей занимался, не было ни одного из необходимых справочников, и мне удалось получить лишь несколько фотографий отдельных страниц (сделать микрофильм книги было невозможно) $)^{30}$. Чтобы проект в конце концов удался, мне понадобилось еще раз изучить рукопись и расширить заметки, которые я сделал ранее. Этот случай, конечно же, напоминает о том, с какими трудностями могут столкнуться ученые, работая в областных библиотеках даже на территории России. Несмотря на всю ценность собрания, которым обладает Кировская областная библиотека имени Герцена, в ней нет большинства важных альбомов с водяными знаками; очевидно, полностью отсутствуют справочники, необхо-

${ }^{29}$ См.: [Waugh, 2004b]; краткое резюме этой статьи на русском: [Уо, 2004]. Части этого материала касается и моя статья [Уо, 2006].

${ }^{30}$ Мое описание ташкентской рукописи [Уо, 2003, с. 262-284] намного лучше всего, что я написал для книги Кинана и своей собственной монографии о письмах султана. Тем не менее в ней много недочетов: необходимо должным образом идентифицировать тексты, более подробно изучить водяные знаки (что я сделал хотя бы схематично), проанализировать и изобразить различные почерки. Благодаря усилиям С. М. Каштанова и Е. С. Смирновой мне удалось использовать книгу из той же личной библиотеки Семена Попова, где хранилась ташкентская рукопись: они помогли мне получить из Казани ее частичную ксерокопию. 
димые тем, кто изучает рукописи, хранящиеся в местном историческом музее. В Ташкенте сейчас, возможно, не придают особого значения небольшому собранию книг на старославянском; в Кирове же, где материала намного больше, люди относятся к нему с большим вниманием, но лишены возможности должным образом его изучать. Трудным может быть даже получение свежих изданий классических работ из Москвы и Санкт-Петербурга: с распадом Советского Союза разрушилась система, благодаря которой важные книги распределялись по местным библиотекам за небольшую цену или бесплатно.

Хотелось бы думать, что моя книга о Вятке доказывает, что молодые годы, которые я провел, учась работе над московскими рукописями, вдохновленный русскими коллегами, принесли настоящие плоды. И что эти плоды - не просто внимание к решению мелких задач относительно текстов, контекстов и документальных свидетельств. Если обстоятельства будут складываться благоприятно, мои первые исследования дадут жизнь еще по крайней мере одной книге. Эта книга будет посвящена тому, как в Московское государство попадали зарубежные новости; одно время я надеялся написать монографию на эту тему, отказался от проекта, но затем возродил его, сотрудничая с Ингрид Майер. Вероятно, это уже будет совершенно иная книга, чем могла бы быть, если бы я завершил ее в 1980-е: сейчас мне хочется задать другие вопросы о текстах и поместить их в такие контексты, о которых я тогда бы и не подумал. Благодаря поездке в Вятку я поменял свои приоритеты и - что звучит иронично - расширил кругозор. Раньше, думая о книге про новости, я хотел сопоставить московский материал с тем, как они появлялись и распространялись в других европейских странах. Но сейчас вижу, что сам московский контекст необходимо вывести за пределы обсуждения той роли, которую играл Посольский приказ в «европеизации» страны. Интерес, который представляют некоторые переводы новостей и памфлетов, можно лучше понять, принимая во внимание, что в народе история и сказки связывались с провидением, а также помня про народные религиозные обряды (например, крестные ходы и паломничество). Значение имели не только такие «современные» институты, как пресса и почта; неформальные, или «традиционные», способы общения (в том числе молва и сплетни) сохраняли свою важность.

Таким образом, я довольно далеко отошел от желания работать в рамках парадигм Соловьева и Ключевского, руководствуясь тем, как изучали тексты мои российские коллеги. В своих исследованиях они обращали внимание на мелкие проблемы; это отчасти объяснялось тем, что в советских условиях ученые были вынуждены избегать многих более масштабных теоретических и интерпретационных подходов. Я не хочу сказать, что ценность этих научных традиций 
уменьшилась: сегодня необходимо следовать принципам качественного изучения рукописей и текстов, и благодаря соблюдению этих принципов постепенно заполняются пробелы в нашем знании источников. Однако существует опасность, что ученый останется слишком привязан к историко-филологическим методам конца XIX в., в то время как в современную эпоху необходимо задавать новые вопросы и расширять горизонты, чтобы двигать науку вперед. Вероятно, вопреки всяким разумным ожиданиям мне удалось оформить свое исследование в соответствии с русскими стандартами, вот почему столько моих работ было издано в России в то время, когда зарубежных ученых там публиковали относительно мало. Сегодня может показаться, что во всем этом нет ничего особенного: теперь существуют совместные проекты, часто проводятся международные конференции, западные ученые постоянно печатаются в русских журналах (а русские - в западных) и на работы первых часто ссылаются, если они переведены на русский. Даже за такой короткий период произошли потрясающие изменения.

У моего скромного успеха в те молодые годы была и обратная сторона. Исследования, которыми я хотел заниматься, не соответствовали тому, что в Америке считалось исторической наукой. Если ученый публиковал статьи не на английском языке в таких престижных в России журналах, как «ТОДРЛ» и «Археографический ежегодник» («АЕ»), это не всегда служило аргументом для его повышения и назначения на должность преподавателя. Что касается языка, не существовало способа удовлетворить оба научных сообщества. Если вы издавали статью на английском, ваши русские коллеги могли ее никогда не прочитать, потому что не смогли бы ее достать или потому что не знали языка. Именно поэтому я решил писать книгу о Вятке на русском, чтобы ее напечатали в СанктПетербурге, хотя это далось мне с большим трудом (западные издатели в любом случае могли не принять эту работу из-за темы). Даже сегодня, когда большинство русских ученых свободно сотрудничают со своими западными коллегами, некоторые из лучших российских исследователей плохо говорят по-английски. Конечно, у зарубежных русистов нет языкового барьера, который бы мешал им пользоваться публикациями на русском, но получить их все же бывает трудно: многие издания выходят маленькими тиражами и в отдаленных городах. В XXI в. необходимо, чтобы все научные работы были доступны через Интернет.

Самая настоящая проблема в американском научном сообществе возникает, когда работу на иностранном языке должны оценивать те, кто не занимается данной областью и не знает ни одного языка, кроме английского. Когда я закончил свою диссертацию в 1972 г., мне очень повезло: я получил одну из двух должностей специалиста по истории России до Нового времени, на которые 
тогда объявлялся конкурс в США ${ }^{31}$. Естественно, мои работы могли читать не многие ученые из моего университета, и это сыграло свою роль несколько лет спустя, когда рассматривался вопрос о повышении. По иронии судьбы, мой руководитель Дональд Тредгольд, который специализировался на истории России Нового времени и мог читать мои публикации, пренебрежительно заявил, что они не являются «историей» ${ }^{32}$. В его понимание того, чем должен заниматься историк, не входили ни написание работ по кодикологии и водяным знакам, ни анализ и публикация малоизвестных древнерусских текстов. Мне кажется, что и в других западных научных учреждениях ситуация сегодня не сильно бы отличалась: исследования по русистике все чаще считаются неактуальными и, по мере того как представители моего поколения выходят на пенсию или умирают, исчезают немногие должности, связанные с историей России до Нового времени. Мы приближаемся к тому дню, когда в США будет невозможно учиться в аспирантуре

31 Мой гарвардский куратор Роберт Ли Вульф, чьи работы были широко известны, написал сильное письмо в мою поддержку. Мне помогло и то, что в 1963 г. я участвовал в летней программе по русскому языку, которой руководил Герберт Эллисон. Тогда он работал историком в Вашингтонском университете. На съезде Американской ассоциации славистов в Денвере в 1971 г., когда мое назначение на должность в Вашингтонском университете рассматривалось как возможное, Эллисон пригласил меня на завтрак с ним и еще двумя будущими моими коллегами, Дональдом Тредгольдом и Питером Шугаром. Что касается второй должности, на которую объявлялся конкурс в 1972 г., в Индианском университете, меня даже не пригласили на собеседование, и на это место взяли Чарльза Гальперина. В Вашингтонский университет, с которым связана вся моя карьера, я изначально был принят на один год вместо вышедшего в отставку Марка Шефтеля, поэтому мне не нужно было приезжать туда для полного формального собеседования (когда меня взяли на работу, я все еще находился в СССР). Изначально намеревались пригласить на год специалиста по истории Польши, но не получилось, и факультет решил взять другого человека, чтобы не потерять эту должность совсем. Когда впоследствии было решено сохранить место историка Древней Руси, факультет тщательным образом изучил мою деятельность в первый год работы. На мое место вполне могли принять кого-то другого, потому что мои первые шаги в преподавании не производили большого впечатления.

32 Являясь деканом исторического факультета, Тредгольд отклонил предложение о том, чтобы повысить меня на год раньше обычного (за это проголосовали многие сотрудники факультета). В следующем году, когда этот вопрос был поднят в обязательном порядке, я отказался от должности главы секции славянских языков в библиотеке Гарвардского университета, и, мне кажется, он был этим разочарован (я подал заявление на это место, когда еще не знал, возьмут ли меня преподавателем). В своем убедительном рекомендационном письме Нед Кинан, бесспорно, надеялся, что я приму предложение из Гарварда. Оглядываясь назад, я думаю, что в Гарварде мной были бы разочарованы, потому что мне нужно было бы слишком многому учиться, чтобы делать свою работу хорошо. Мои обязанности в Вашингтонском университете усложнялись тем, что я одновременно работал на факультетах истории и международных исследований (а это означало, что за мое назначение и повышение голосовали группы с двух разных факультетов и с разными академическими приоритетами). В последние годы работы в университете я перенес половину своих обязанностей с факультета международных исследований на факультет славянских языков, начав вести там курс по древнерусской литературе и культуре. Таким образом, ко времени моего выхода в отставку я работал на трех факультетах. 
по этому направлению и, если на то пошло, по многим другим областям истории данного периода ${ }^{33}$.

По крайней мере сейчас, находясь в отставке, я больше не беспокоюсь о получении работы и о рассмотрении кандидатов на продвижение. Но мне приходится заботиться о том, чтобы мои труды были достойны чтения и о том, чтобы среди горсточки ученых оставались те, кто так же, как я, увлечен темами нашего общего интереса. Если мои исследования принесли какую-то пользу, то должен признать, что вдохновение и поддержку для этого я получил не только от преподавателей, но и от своих российских коллег. Их профессионализм находится на таком уровне, к которому я до сих пор могу лишь стремиться.

Амосов A. A. Проблема точности филигранологических наблюдений. 1. Терминология // Проблемы научного описания рукописей и факсимильного издания памятников письменности: материалы Всесоюзной конференции / ред. М. В. Кукушкина, С. О. Шмидт. Л. : Наука, 1981. С. 70-91.

Амосов А. А., Колесников П. А. Опыт и перспективы описания документальных памятников в местных хранилищах («Вологодская программа»: сущность, результаты и задачи) // Археографический ежегодник за 1986 г. М. : Наука, 1987.

Андрюшайтите Ю. В. С. А. Клепиков - основатель отечественной библиографии по филигранологии // Археографический ежегодник за 1986 г. М. : Наука, 1987a. C. $121-130$.

Андрюшайтите Ю. В. Развитие советского филиграноведения в 50-х - начале 80-х годов // Археографический ежегодник за 1985 год. М. : Наука, 1987б. С. 157.

Бобров А. Г., Рождественская Т. В. Вячеслав Михайлович Загребин (31.10.1942 09.10.2004): Некролог // ТОДРЛ. 2006. Т. 57. С. 984-987.

Богданов А. П. Основы филиграноведения. История, теория, практика. М. : Эдиториал УРСС, 1999. 336 с.

Дианова Т. В. Метод датировки документов с помощью водяных знаков и принципы публикации филиграней // Археографический ежегодник за 1974 год. М. : Наука, 1975. С. 56-61.

Каган М. Д., Понырко Н. В., Рождественская М. В. Описание сборников XV в. книгописца Ефросина // ТОДРЛ. 1980. Т. 35. С. 3-300.

Кореикий В. И. Безднинский летописец конца XVI в. из собрания С. О. Долгова // Записки Отдела рукописей ГБЛ. 1977. Вып. 38. С. 190-208.

\footnotetext{
${ }^{33}$ Когда в отставку ушли я и Герберт Эллисон, специалист по истории ХХ в., исторический факультет получил разрешение заполнить только одну должность, и выбрали вторую. На факультете славянских языков Вашингтонского университета больше нет специалиста по древнерусской литературе. Я провел в Вашингтонском университете более тридцати лет и за это время был научным руководителем только по четырем докторским диссертациям, относящимся к моей области (и еще в одном, последнем случае был внешним членом диссертационного совета). Эти диссертации написали: Роберт Кроски, изучавший дипломатию в Московском государстве, Дэвид Дэс «Скифскую историю» Андрея Лызлова, Изольда Тире - женскую религиозную жизнь, Томас Дикстра - Иосифо-Волоколамский монастырь и Клавдия Дженсен - она училась истории музыки в Принстоне и писала о Николае Дилецком. В других университетах в последние несколько десятилетий вышли на пенсию и умерли некоторые выдающиеся американские специалисты по Древней Руси. Среди них - Кинан, Роберт Крамми, Ричард Хэлли и Густав Алеф. В большинстве случаев им не нашлось замены. Некоторые из лучших специалистов по истории России до Нового времени, принадлежащие к следующему поколению, преподают там, где нет возможности работать с аспирантами по данной области. Новости из Западной Европы для будущего русистики также неутешительны: под угрозой находятся целые программы.
} 
Кукушкина М. В. Сократ Александрович Клепиков (К 90-летию со дня рождения) // Исследования по истории общественного сознания эпохи феодализма в России. Новосибирск, 1984. С. 202-112.

Майер И., Шамин С. «Легендарное послание турецкого султана немецким владетелям и всем христианам» (1663-1664 гг.). К вопросу о распространении переводов европейских памфлетов из Посольского приказа в рукописных сборниках // Древняя Русь. Вопросы медиевистики. 2007. Т. 4. № 30. С. 80-89.

Морозов Б. Н. Первое послание Курбского Ивану Грозному в сборнике конца XVI начала XVII в. // Археографический ежегодник за 1986 г. М. : Наука, 1987. С. 277-289.

Описание рукописей Синодального собрания (не вошедших в описание А. В. Горского и К. И. Невоструева / сост. Т. Н. Протасьева. Ч. 1-2. М. : Гос. исторический музей, 1970-1973.

Сводный каталог славяно-русских рукописных книг, хранящихся в России, странах СНГ и Балтии. XIV век. Вып. 1: Апокалипсис - Летопись Лаврентьевская. М. : Индрик, 2002.

Сводный каталог славяно-русских рукописных книг, хранящихся в СССР. XI-XIII вв. М. : Наука, 1984.

Уо Д. К. Анатольевский сборник и проблемы вятского летописания // Шведы и Русский север: историко-культурные связи: (К 210-летию Александра Лаврентьевича Витберга): материалы Международного научного симпозиума. Киров, 1997а. C. 336-354.

Уо Д. К. История одной книги. Вятка и «не-современность» в русской культуре Петровского времени. СПб. : Дмитрий Буланин, 2003. 394 с.

Уо Д. К. К вопросу о датировке Великорецкого крестного хода // Герценка: Вятские записки. Вып. 6. Киров, 2004. С. 128-136.

Уо Д. К. К истории вятского летописания // In Memoriam: сборник памяти Я. С. Лурье / сост. Н. М. Ботвинник, Е. И. Ванеева. СПб. : Antheneum-Феникс, 1997б. С. 303-320.

Уо Д. К. Кто на самом деле «провинциален»? Размышления о концепции провинциальности на примерах России раннего Нового времени, Западной Европы и Америки // Книга и литература в культурном пространстве эпох (XI-XX века) / сост. и отв. ред. О. Н. Фокина, В. Н. Алексеев. Новосибирск : ГПНТБ СО РАН, 2011. С. 51-58.

Уо Д. К. Местное самоуправление, религия и «изобретение» регионального прошлого // ТОДРЛ. 2006. Т. 57. С. 350-358.

Уо Д. К. Неизвестный памятник древнерусской литературы: «Грамота государя царя и великого князя Ивана Васильевича всея Руси к Степану, королю польскому» // Археографический ежегодник за 1971 год. М. : Наука, 1972. С. 357-361.

Friedman V. A. The Zaporozhian Letter to the Turkish Sultan: Historical Commentary and Linguistic Analysis // Slavica Hierosolymitana. 1978. Vol. 2. P. 24-37.

Maier I. Acht anonyme deutsche und polnische „Sabetha Sebi“-Drucke aus dem Jahre 1666. Auf der Spur nach dem Drucker // Gutenberg-Jahrbuch. 2008. Vol. 83. S. $141-160$.

Maier I. „Ontsegh-brief van den Turckschen Keyser..." Ein fiktiver Brief des türkischen Sultans an den König von Polen in russischer Übersetzung (1621) // Jako blagopesnivaja ptica. Hyllningsskrift till Lars Steensland / ed. by P. Ambrosiani, I. Lysén et al. Stockholm, 2006 (= Stockholm Slavic Papers 32). S. 135-146.

Maier I., Waugh D. How Well Was Muscovy Connected with the World? // Imperienvergleich: Beispiele und Anätze aus osteuropäischer Perspektive. Festschrift für Andreas Kappeler / ed. by G. Hausmann, A. Rustemeyer. Wiesbaden: Harrassowitz, 2009 (= Forschungen zur osteuropäischen Geschichte, Bd. 75). S. 17-38.

Maier I., Waugh D. "The Blowing of the Messiah's Trumpet": Reports about Sabbatai Sevi and Jewish Unrest in 1665-1667 // The Dissemination of News and the Emergence of Contemporaneity in Early Modern Europe / ed. by B. Dooley. Farnham, Surrey ; Burlington, VT : Ashgate Publishing, 2010. P. 137-152.

Marker G. Daniel' Uo [Daniel Clarke Waugh], Istoriia odnoi knigi: Viatka i "nesovremennost'” v russkoi kul'ture petrovskogo vremeni // Jahrbücher für Geschichte Osteuropas. 2005. Vol. 53. No. 1. S. 116-117.

Waugh D. "Anatolii's Miscellany" - Its Origins and Migration // Harvard Ukrainian Studies. 1995. Vol. 19. P. 747-755.

Waugh D. Discovering Vyatka // REECAS Newsletter. 1997 (Winter). Vol. 2-3. P. 15.

Waugh D. For What Purpose Did an American Come to Lal'sk // REECAS Newsletter. 2004a (Spring). 
Waugh D. News of the False Messiah: Reports on Shabbetai Zevi in Ukraine and Muscovy // Jewish Social Studies. 1979a. Vol. 41. No. 3-4. P. 301-322.

Waugh D. News Sensations from the Front: Reportage in Late Muscovy concerning the Ottoman Wars // Rude \& Barbarous Kingdom Revisited: Essays in Russian History and Culture in Honor of Robert O. Crummey / ed. by Ch. Dunning, R. Martin, D. Rowland. Bloomington, IN. : Kritika, 2008. P. 491-506 + 2 plates.

Waugh D. On the Origin of the "Correspondence" between the Sultan and the Cossacks // Recenzija: A Review of Soviet Ukrainian Scholarly Publications. 1971. Vol. 1. No. 2. P. 3-46.

Waugh D. Ralph Cleminson (comp.), A Union Catalogue of Cyrillic Manuscripts in British and Irish Collections // Canadian-American Slavic Studies. 1990. Vol. 24. No. 4. P. 457-458.

Waugh D. Religion and Regional Identities: the Case of Viatka and the Miracle-Working Icon of St. Nicholas Velikoretskii // Die Geschichte Russlands im 16. und 17. Jahrhundert aus der Perspektive seiner Regionen / hrsg. von A. Kappeler. Wiesbaden: Harrassowitz, 2004 b (=Forschungen zur osteuropäischen Geschichte 63). S. 259-278.

Waugh D. The Great Turkes Defiance: On the History of the Apocryphal Correspondence of the Ottoman Sultan in Its Muscovite and Russian Variants / with a foreword by Academician D. S. Likhachev. Columbus. O. : Slavica, 1978. ix, 354 p.

Waugh D. The Lessons of the Kurbskii Controversy Regarding the Study and Dating of Old Russian Manuscripts // Russian and Slavic History / ed. by Don K. Rowney, G. Edward Orchard. Columbus, O. : Slavica, 1977. P. 218-237.

Waugh D. The Publication of the Muscovite Kuranty// Kritika. 1973. Vol. 9. No. 3. P. 103-120.

Waugh D. Two Unpublished Muscovite Chronicles // Oxford Slavonic Papers. N. S. 1979b. Vol. 12. P. 1-31.

Waugh D. Soviet Watermark Studies - Achievements and Prospects // Kritika. 1970. Vol. 6. No. 2. P. 78-111.

Waugh D. We Have Never Been Modern: Approaches to the Study of Russia in the Age of Peter the Great // Jahrbücher für Geschichte Osteuropas. 2001. Vol. 49. P. 321-345.

Amosov, A. A. (1981). Problema tochnosti filigranologicheskih nablyudenij. 1. Terminologiya [The problem of accuracy of filigranologic observation. 1. Terminology]. In M. V. Kukushkina, S. O. Shmidt (Eds.), Problemy' nauchnogo opisaniya rukopisej $i$ faksimil'nogo izdaniya pamyatnikov pis'mennosti: materialy' Vsesoyuznoj konferencii (p. 70-91). Leningrad: Nauka.

Amosov,A.A.\& Kolesnikov, P.A.(1987). Opy't i perspektivy' opisaniya dokumental'ny'h pamyatnikov v mestny'h hranilishhah ("Vologodskaya programma": sushhnost', rezul'taty' i zadachi) [Experience and perspectives of the description of documentary monuments in local archives ("Vologda program": main points, results, tasks)]. In Arheograficheskij ezhegodnik za 1986 god. Moscow: Nauka.

Andryushajtite, Yu. V. (1987). Razvitie sovetskogo filigranovedeniya v 50-h - nachale 80 -h godov [The development of the Sovet filigranology in 50s - early 80s yrs.]. In Arheograficheskij ezhegodnik za 1985 god. Moscow: Nauka.

Andryushajtite, Yu. V. (1987). S. A. Klepikov - osnovatel' otechestvennoj bibliografii po filigranologii [S. A. Klepikov - founder of the national bibliography on filigranology]. In Arheograficheskij ezhegodnik za 1986 god (p. 121-130). Moscow: Nauka.

Bobrov, A. G. \& Rozhdestvenskaya, T. V. (2006). Vyacheslav Mihajlovich Zagrebin (31.10.1942-09.10.2004): Nekrolog [Vyacheslav Mikhailovich Zagrebin (31.10.1942-09.10.2004): obituary]. In TODRL. (Vol. 57, p. 984-987).

Bogdanov, A. P. (1999). Osnovy' filigranovedeniya. Istoriya, teoriya, praktika [Basis of filigranology. History, theory, practice]. Moscow: E'ditoral URSS.

Dianova, T. V. (1975). Metod datirovki dokumentov s pomosh'yu vodyany'h znakov i principy' publikacii filigranej [The method of dating documents by means of watermarks and the principles of filigree publication]. In Arheograficheskij ezhegodnik za 1974 god (p. 56-61). Moscow: Nauka.

Friedman, V. A. (1978). The Zaporozhian Letter to the Turkish Sultan: Historical Commentary and Linguistic Analysis. In Slavica Hierosolymitana. (Vol. 2, p. 24-37).

Kagan, M. D., Pony'rko, N. V. \& Rozhdestvenskaya, M. V. (1980). Opisanie sbornikov $\mathrm{XV}$ v. knigopiscza Efrosina [The description of collections of XV century of copyist Euphrosynus]. In TODRL. (Vol. 35, p. 3-300). 
Koreczkij, V. I. (1977). Bezdninskij letopisecz koncza XVI v. iz sobraniya S. O. Dolgova [Bezdninsky chronicler of the late $16^{\text {th }}$ century from S. O. Dolgov's collection]. In Zapiski Otdela rukopisej GBL (Vol. 38, p. 190-208).

Kukushkina, M. V. (1984). Sokrat Aleksandrovich Klepikov (K 90-letiyu so dnya rozhdeniya) [Socrat Aleksandrovich Klepikov (To the $90^{\text {th }}$ anniversary of the birth)]. In Issledovaniya po istorii obshhestvennogo soznaniya e'pohi feodalizma v Rossii (p. 202212). Novosibirsk.

Maier, I. (2006). „Ontsegh-brief van den Turckschen Keyser...“ Ein fiktiver Brief des türkischen Sultans an den König von Polen in russischer Übersetzung (1621). In P. Ambrosiani, I. Lysén et al. (Eds.). Jako blagopesnivaja ptica. Hyllningsskrift till Lars Steensland. (Vol. 32, p. 135-146). Stockholm (= Stockholm Slavic Papers).

Maier, I \& Shamin, S. (2007). "Legendarnoe poslanie tureczkogo sultana nemeczkim vladetelyam i vsem hristianam” (1663-1664 gg.). K voprosu o rasprostranenii perevodov evropejskih pamfletov iz Posol'skogo prikaza v rukopisny'h sbornikah ["Legendary message of the Turkish Sultan to German owners and all Christians" (1663-1664 yrs.). Revisiting the spread of the translations of European pamphlets out of the Ambassadorial order in manuscript collections]. Drevnyaya Rus'. Voprosy' medievistiki, 4/30, 80-89.

Maier, I. (2008). Acht anonyme deutsche und polnische „Sabetha Sebi“-Drucke aus dem Jahre 1666. Auf der Spur nach dem Drucker. In Gutenberg-Jahrbuch (Vol. 83, p. 141-160).

Maier, I. \& Waugh, D. (2009). How Well Was Muscovy Connected with the World? In G. Hausmann, A. Rustemeyer (Eds.), Imperienvergleich: Beispiele und Anätze aus osteuropäischer Perspektive. Festschrift für Andreas Kappeler. (Vol. 75, p. 17-38). Wiesbaden: Harrassowitz (= Forschungen zur osteuropäischen Geschichte).

Maier, I. \& Waugh, D. (2010). "The Blowing of the Messiah's Trumpet": Reports about Sabbatai Sevi and Jewish Unrest in 1665-1667. In B. Dooley (Ed.), The Dissemination of News and the Emergence of Contemporaneity in Early Modern Europe (p. 137-152). Farnham, Surrey; Burlington, VT: Ashgate Publishing.

Marker, G. (2005). Daniel' Uo [Daniel Clarke Waugh], Istoriia odnoi knigi: Viatka i "ne-sovremennost"” v russkoj kul'ture petrovskogo vremeni. Jahrbücher für Geschichte Osteuropas, 53/1, 116-117.

Morozov, B. N. (1987). Pervoe poslanie Kurbskogo Ivanu Groznomu v sbornike koncza XVI - nachala XVII v. [The first massage of Kurbsky to Ivan the Great in the collection of the late $16^{\text {th }}$ - early $17^{\text {th }}$ c.]. In Arheograficheskij ezhegodnik za 1986 god (p. 277-289). Moscow: Nauka.

Protas'eva, T. N. (Comp.). (1970-1973). Opisanie rukopisej Sinodal'nogo sobraniya (ne voshedshih $v$ opisanie A. V. Gorskogo $i K$. I. Nevostrueva) [Description of the manuscripts of the Synodal Assembly (not included in the description by A. V. Gorsky and K. I. Nevostruev)]. Part 1-2. Moscow: Gos. istoricheskij muzej.

Svodny'j katalog slavyano-russkih rukopisny'h knig, hranyashhihsya v Rossii, stranah SNG i Baltii. XVI vek. Vy'p. 1: Apokalipsis - Letopis' Lavrent'evskaya [Central catalogue of the Salvonic-Russian manuscript books, kept in Russia, CIS and Baltic countries. $16^{\text {th }}$ century. Iss. 1: Apocalypse-Laurentian Chronicle]. (2002). Moscow: Indrik.

Svodny'j katalog slavyano-russkih rukopisny'h knig, hranyashhihsya v SSSR. XI-XIII $v v$. [Central catalogue of the Salvonic-Russian manuscript books, kept in the USSR. $11^{\text {th }}$ $13^{\text {th }}$ cc.]. (1984). Moscow: Nauka.

Waugh, D. K. (1970). Soviet Watermark Studies - Achievements and Prospects. Kritika, 6/2, 78-111.

Waugh, D. K. (1971). On the Origin of the "Correspondence" between the Sultan and the Cossacks. Recenzija: A Review of Soviet Ukrainian Scholarly Publications, 1/2, 3-46.

Waugh, D. K. (1972). Neizvestny'j pamyatnik drevnerusskoj literatury': “Gramota gosudarya czarya i velikogo knyazya Ivana Vasil'evicha vseya Rusi k Stepanu, korolyu pol'skomu" [Unknown Old Russian literature monument: "A Letter of tsar and grand prince of All Russia Ivan Vasilyevich to Stepan, king of Poland"']. In Arheograficheskij ezhegodnik za $1971 \operatorname{god}($ p. 357-361). Moscow: Nauka.

Waugh, D. K. (1973). The Publication of the Muscovite Kuranty. Kritika, 9/3, 103-120.

Waugh, D. K. (1977). The Lessons of the Kurbskii Controversy Regarding the Study and Dating of Old Russian Manuscripts. In Don K. Rowney, G. Edward Orchard (Eds.), Russian and Slavic History (p. 218-237). Columbus, O.: Slavica.

Waugh, D. K. (1978). The Great Turkes Defiance: On the History of the Apocryphal Correspondence of the Ottoman Sultan in Its Muscovite and Russian Variants. Academician D. S. Likhachev (Foreword). Columbus. O.: Slavica. 
Waugh, D. K. (1979). News of the False Messiah: Reports on Shabbetai Zevi in Ukraine and Muscovy. Jewish Social Studies, 41/3-4, 301-322.

Waugh, D. K. (1979). Two Unpublished Muscovite Chronicles. In Oxford Slavonic Papers. N.S. (Vol. 12, p. 1-31).

Waugh, D. K. (1990). Ralph Cleminson(Comp.), A Union Catalogue of Cyrillic Manuscripts in British and Irish Collections. Canadian-American Slavic Studies, 24/4, 457-458.

Waugh, D. K. (1995). “Anatolii’s Miscellany" - Its Origins and Migration. In Harvard Ukrainian Studies. (Vol. 19, p. 747-755).

Waugh, D. K. (1997). Anatol'evskij sbornik i problemy' vyatskogo letopisaniya [Anatoly miscellany and the problems of Vyatka chronicle writing]. In Shvedy' $i$ Russkij sever: istoriko-kul'turny'e svyazi: (K 210-letiyu Aleksandra Lavrent'evicha Vitberga): materialy' mezhdunarodnogo nauchnogo simpoziuma (p. 336-354). Kirov.

Waugh, D. K. (1997). Discovering Vyatka. In REECAS Newsletter. (Vol. 2-3).

Waugh, D. K. (1997). K istorii vyatskogo letopisaniya [Revisiting Vyatka chronicle writing]. In N. M. Botvinnik, E. I. Vaneeva (Comp.), In Memoriam: sbornik pamyati Ya. S. Lur'e [In Memoriam: collection in memory of J. S. Lurie] (p. 303-320). St. Petersburg: Antheneum-Feniks.

Waugh, D. K. (2001). We Have Never Been Modern: Approaches to the Study of Russia in the Age of Peter the Great. In Jahrbücher für Geschichte Osteuropas. (Vol. 49, p. 321-345).

Waugh, D. K. (2003). Istoriya odnoj knigi. Vyatka $i$ "ne-sovremennost"” v russkoj kul'ture Petrovskogo vremeni [History of one book. Vyatka and "pastness" in Russian culture in the time of Peter the Great]. St. Petersburg: Dmitrij Bulanin.

Waugh, D. K. (2004). For What Purpose Did an American Come to Lal'sk. In REECAS Newsletter.

Waugh, D. K. (2004). K voprosu o datirovke Velikoreczkogo krestnogo hoda [Revisiting the dating of Velikoreczk religious procession]. In Gercenka: Vyatskie zapiski. (Vol. 6, p. 128-136). Kirov.

Waugh, D. K. (2004). Religion and Regional Identities: the Case of Viatka and the Miracle-Working Icon of St. Nicholas Velikoretskii. In A. Kappeler (Ed.), Die Geschichte Russlands im 16. und 17. Jahrhundert aus der Perspektive seiner Regionen (p. 259-278). Wiesbaden: Harrassowitz (=Forschungen zur osteuropäischen Geschichte).

Waugh, K. D. (2006). Mestnoe samoupravlenie, religiya i "izobretenie" regional'nogo proshlogo [Local government, religion and "invention" of the regional past]. In TODRL. (Vol. 57, p. 350-358).

Waugh, D. K. (2008). News Sensations from the Front: Reportage in Late Muscovy concerning the Ottoman Wars. In Ch. Dunning, R. Martin, D. Rowland (Eds.), Rude \& Barbarous Kingdom Revisited: Essays in Russian History and Culture in Honor of Robert O. Crummey (p. 491-506 + 2 plates). Bloomington, IN.: Kritika.

Waugh, D. K. (2011). Kto na samom dele “provincialen”? Razmy'shleniya o koncepcii provincial'nosti na primerah Rossii rannego Novogo vremeni, Zapadnoj Evropy' i Ameriki [Who is "provincial" in fact? Reflections of the concept of provincialism by the examples of Russia, Western Europe and America]. In O. N. Fokina, V. N. Alekseev (Eds., Comp.), Kniga i literatura v kul'turnom prostranstve e'poh (XI-XX veka) (p. 51-58). Novosibirsk: GPNTB SO RAN.

Translated by Elena Galitsyna

The article was submitted on 30.04.2014

\section{Даниель Уо}

почетный профессор

США, Сиэтл

Вашингтонский университет

dwaugh@u.washington.edu

\author{
Daniel Waugh \\ Professor Emeritus \\ USA, Seattle \\ University of Washington \\ dwaugh@u.washington.edu
}

